\title{
TORT LAW IN THE ERA OF CLIMATE CHANGE, KATRINA, AND 9/11: EXPLORING LIABILITY FOR EXTRAORDINARY RISKS
}

\author{
Daniel A. Farber* \\ I. INTRODUCTION
}

Tort cases generally deal with routine risks - the kind of risk that a person encounters as a result of driving a car or buying a product. Such risks are also staples of the insurance industry. Today, however, society faces risks that threaten potentially massive harms to large segments of the public. Katrina destroyed the city of New Orleans, claiming 1,464 victims ${ }^{1}$ and causing well over $\$ 22.6$ billion $^{2}$ in property damage. Much of the damage might have been avoided if the city's flood control system had performed as designed. A few years earlier, terrorist attacks on 9/11 destroyed the World Trade Center, claiming 2,752 victims ${ }^{3}$ and causing over $\$ 18.8$ billion $^{4}$ in property damage. Climate change may already be responsible for tens of thousands of deaths and will ultimately cause many billions of dollars worth of damage. ${ }^{5}$

Can tort law strengthen society's response to these risks? In part, the answer to this question may depend on whether we see tort law as exclusively a matter of enforcing private rights, or whether we see it as also encompassing public law goals such as deterrence and risk spreading. In any event, judges have begun to confront this question,

\footnotetext{
Sho Sato Professor of Law and Faculty Director of the California Center for Environmental Law and Policy, University of California, Berkeley. Work on this article was partially funded by National Science Foundation grant \# 0624296. I would like to thank Rosario Caledon and Josh Benson for research assistance, and Michael Hanemann, Elaine Shoben, and David Anderson for helpful comments on earlier drafts. An earlier version of this essay was presented as the 2008 Monsanto Lecture on Tort Theory at Valparaiso University School of Law.

1 Louisiana Department of Health and Hospitals, Deceased Reports: Reports of Missing and Deceased (Aug. 2, 2006), available at http://www.dhh.louisiana.gov/offices/page.asp? ID=192\&Detail=5248 (last visited Feb. 11, 2009).

2 Press Release, AIR Worldwide, AIR Worldwide Estimates Total Property Damage from Hurricane Katrina's Storm Surge and Flood at \$44 Billion (Sept. 29, 2005), available at http://www.iso.com/index.php?option=com_content\&task=view\&id=2226 (last visited Feb. 11, 2009).

3 Phil Hirschkorn, New York Reduces 9/11 Death Toll by 40, CNN NEw YORK BUREAU, Oct. 29, 2003, http://www.cnn.com/2003/US/Northeast/10/29/wtc.deaths/ (last visited Feb. 11, 2009).

4 Personal Insurance Federation of California, THE TOPIC: Catastrophes/Tsunami's [sic], in 2005 INSURANCE REFERENCE MANUAL, available at http://www.pifc.org/insurance manual/09_earthquake_tsunami.html (last visited Feb. 11, 2009).

$5 \quad$ See supra text accompanying notes $1-4$.
} 
with varying results-some have rejected tort claims, based on these extraordinary risks, as non-justiciable, whereas others have recognized a basis for liability for failure to take precautions against risks such as terrorist acts or natural disasters.

Part II of this Article provides case studies of how the tort system has responded to catastrophic risks such as large-scale flooding, terrorist acts, and climate change. Liability approaches vary depending on the problem and jurisdiction, but there is no consistent pattern of immunity for sources of catastrophic risk. Some courts have shied away from hearing cases involving massive liability exposure, while others have stepped up to the challenge.

Part III examines how tort liability for catastrophic risks could contribute to societal goals of deterring undesirable risks and social riskspreading. As we will see, the risk-spreading goal is particularly important because of the reluctance of private insurers to cover such risks. There are other potential responses to this insurance gap, and in some situations one or another may be superior, but all of them have flaws that preclude any presumption of providing a superior form of risk-spreading compared with tort law.

A few remarks about the scope of this Article are appropriate. To begin, the types of risks discussed in this Article vary considerably, but they have some important commonalities nonetheless. The situations involved typically have three major characteristics. The first characteristic is magnitude. These events involve either major loss of life (probably numbered in thousands rather than hundreds), or extraordinary physical damage and economic harm (on the order of one billion dollars or more). The second is that the events were, at least arguably, caused by human activities, or the damages could have been substantially mitigated through precautionary measures. Otherwise, the tort system would not be relevant. The third major characteristic is that these situations evade at least part of the usual systems for managing risks. For example, asbestos litigation overwhelmed the court system's ability to process disputes, while terrorism and natural disasters have spotty insurance coverage (and what coverage does exist for terrorism and natural disasters tends to be government subsidized).

There is no recognized term for these situations. We could call them disasters, catastrophes, or mega-torts. The corresponding risks could be identified as catastrophic risks or public risks, as opposed to the more garden-variety risks that the legal system manages on a daily basis without significant strain.

There are significant variations within this category. Some disasters, such as the destruction of the World Trade Center, involve dramatic 
discrete events, with enormous damage occurring within a short period. Others, like climate change or asbestos deaths, take place over longer periods of time. There are also borderline cases-events with damages in the hundreds of millions of dollars rather than billions, or leakage from hazardous waste sites (a multi-billion dollar source of clean-up expenses but not of direct damages).

For present purposes, precisely characterizing these risks is unnecessary. My goal is not to advocate the adoption of specific rules about these events or to debate the application of existing doctrinal rules. Rather, I want to explore the ways in which the legal system has responded to compensation demands for massive harms and to consider whether liability in some form would be socially desirable, where defendants were negligent or otherwise engaged in tortuous activities. ${ }^{6}$ The tort system obviously cannot be the sole, or even the primary, legal response to catastrophic risks, but the tort system should be an important part of the mix.

Given that this lecture is part of a series on tort theory, I should also say that I understand the term "torts" to not only center on the common law of torts but also to extend more broadly to other forms of compensation for harms caused by risky behavior. Thus, I view legislatively created judicial remedies and even administrative compensation systems to be tort-like. There are obviously important institutional questions about when courts should devise compensation rules and when they should await legislative action, and also about when judicial remedies are superior to administrative ones. I will touch on these questions, but they are not my central focus. Rather, my main interest rests in a more substantive question: is it appropriate to require those who create extraordinary risks, or fail to take precautions against them, to finance compensation for those who are harmed?

\section{CASE STUDIES}

This Part of the Article considers several major types of risks, including floods, terrorism, climate change, and environmental contamination. All of these risks can be considered "billion dollar babies" in terms of their potential scope of liability. These risks differ in other respects, such as the source of the risk (public entities versus private firms), the number of defendants, and the temporal profile of the

\footnotetext{
6 I say "liability in some form" because as discussed in the text, the question of whether liability should be delivered through the common law tort system or through a statutory judicial or administrative remedy is not my focus, although I will have something to say about the potential virtues of the common law as at least a default source of liability.
} 
risk (one-shot event versus progressive harm). It is useful, however, to begin with an overview of how tort liability fits into society's overall portfolio of strategies for compensating for catastrophic risks.

There is a tendency to assume that these risks are simply too extraordinary for the tort system to handle, presenting a threat of unconfined liability that the legal system cannot manage. The response of the New York courts to a massive power blackout illustrates the tendency to avoid applying normal liability rules to catastrophic system failures. Strauss $v$. Belle Realty $\mathrm{Co}^{7}$ arose from the July 1977 blackout of New York City. In order to avoid what it considered to be a potentially crippling level of liability, the court held that liability would be limited to direct customers of the company, despite the company's blatant negligence that affected many other New Yorkers. ${ }^{8}$

Notably, the court's response was not to eliminate tort liability but to try to confine the class of victims in order to control damages. Even so, it would be a mistake, as discussed below, to assume on the basis of Strauss that the tort system's role is insignificant in handling catastrophic risks.

482 N.E.2d 34 (N.Y. 1985).

8 Id. at 37-38. The plaintiff was injured by falling down a stairwell when the power went out in the common area of an apartment building. Id. at 35 . The fact that the injury was in the common area was critical because in that part of the building, the landlord, rather than the tenant, was the customer of the power company. Id. Based on this fact, the court held that the tenant could not recover, and that any liability from harms caused would be limited to direct clients of the power company. Id. at 37. The court explained further:

[W]e deal here with a system-wide power failure occasioned by what has already been determined to be the utility's gross negligence. If liability could be found here, then in logic and fairness the same result must follow in many similar situations. For example, a tenant's guests and invitees, as well as persons making deliveries or repairing equipment in the building, are equally persons who must use the common areas, and for whom they are maintained. Customers of a store and occupants of an office building stand in much the same position with respect to Con Edison as tenants of an apartment building. In all cases the numbers are to a certain extent limited and defined, and while identities may change, so do those of apartment dwellers. While limiting recovery to customers in this instance can hardly be said to confer immunity from negligence on Con Edison, permitting recovery to those in plaintiff's circumstances would, in our view, violate the court's responsibility to define an orbit of duty that places controllable limits on liability.

Id. at 38 (internal citations omitted). The court also applied the same direct customer rule even when the tenants had an obligation under their lease to compensate the landlord for electricity: the tenants still were not direct customers of the utility. Milliken \& Co. v. Consol. Edison Co., 644 N.E.2d 268 (N.Y. 1994). Thus, the ironic result may be that plaintiffs who could recover if only a few people were injured are barred because the defendant harmed a great many people. 
Strauss may express caution about sweeping liability for mega-risks, but this Article demonstrates that courts are not always unwilling to impose liability.

\section{A. An Overview of Compensation for Catastrophic Risks}

Steps can be taken to limit the human impact of natural disasters. Nevertheless, harm to human life and property cannot be completely avoided. This raises the question of compensation. The legal system provides a mix of public and private sector methods for compensating victims of natural disasters. Each of the methods that have been used to provide compensation for catastrophic risks has its limitations.

The first method of compensation is private insurance. However, the unavailability of insurance for catastrophic risks due to expense or underwriting risks, exclusion of catastrophic risks by contract, and the difficulty of handling very large numbers of claims create significant hurdles. ${ }^{9}$ The second method of compensation, litigation against responsible private parties, also has its limitations: the need for proof of negligence or other basis for liability; limits on the financial assets and insurance coverage of potential defendants; and other judicial doctrines limiting recovery. Third, there is the possibility of obtaining compensation from the government through various routes: tort claims against federal or state government for negligence (subject to immunity defenses); claims under special compensation schemes established for particular disasters; and claims based on constitutional provisions requiring compensation for the taking (or in some states, damaging) of property.

In a sense, it is a mistake to speak of a "system" of compensation for catastrophic losses. Instead, our society has a makeshift assembly of jerry-rigged components:

In the final analysis, the U.S. has what might well be termed a patchwork system for providing financial compensation for catastrophic loss[] ... Inevitably, in such a multifaceted milieu, where the tendency has been to develop discrete schemes in response to particularized categories of disasters (or rely on general welfare schemes that were enacted without disaster relief in mind), there will be ongoing fine-tuning of the system and a continuing dialogue over the efficacy of the measures in place. While the description of the U.S. 
system may not point to a single best model for delivering financial compensation for catastrophic harm in all circumstances, its very complexity indicates the variety of pathways that might be taken. ${ }^{10}$

Because of its common law roots, tort law may be well adapted to filling some of the gaps left in this patchwork. We will now consider how courts have responded to tort claims regarding various forms of catastrophic events. This survey covers floods, climate change, disease (cancer), and a form of war (terrorism) - not quite the Four Horsemen of the Apocalypse, but certainly bad enough.

\section{B. Flood Risks}

Flood risks are a useful place to start because of the diverse approaches to tort liability for defective flood control systems. California provides broad liability for governmental entities that own or operate flood control systems, but the federal government has been granted broad immunity from liability.

\section{A Case Study: California's Liability System}

California law provides an example of the role that judicially imposed compensation can play. The California Supreme Court developed liability rules for levee failures in three cases. These cases are based in part on the California Constitution's version of the Takings Clause, which refers to "taking or harming" of property. It would be a mistake, however, to marginalize the California cases as involving an arcane state constitutional doctrine. The California cases use tort concepts and move without much evident concern between common law tort and state constitutional analysis. The court's primary concern seems to be risk-spreading.

The modern development of flood liability in California began with Belair v. Riverside County Flood Control District. ${ }^{11}$ In Belair, a flood control levee on the San Jacinto River gave way, flooding parts of the City of San Jacinto. The California Supreme Court took this occasion to establish a new rule for determining the state's responsibility for flood damages, based firmly on the need to spread the risks created by unreasonably flawed flood control systems:

10 Robert L. Rabin \& Suzanne A. Bratis, United States, in FINANCIAL COMPENSATION FOR VICTIMS OF CATASTROPHES: A COMPARATIVE APPROACH 303, 356 (Michael Faure \& Ton Hartlief eds., 2006).

$11 \quad 764$ P.2d 1070 (Cal. 1988). 
Permitting recovery where the public entity's unreasonable conduct constitutes a substantial cause of damage to property owners negates the apprehension commonly associated with a rule of absolute liability the discouragement of beneficial flood control improvements-yet properly compensates for losses unfairly incurred.... Reasonableness, in this context, is not entirely a matter of negligence, but represents a balancing of public need against the gravity of private harm.12

Consequently, the California court created a form of liability for defective levees, somewhat reminiscent of liability for manufacturing a defective product:

The reasonableness of the public agency's conduct must be determined on the facts of each individual case, taking into consideration the public benefit and the private damages in each instance.... Inverse condemnation liability ultimately rests on the notion that the private individual should not be required to bear a disproportionate share of the costs of a public improvement... Thus, compensation for damages incurred as the result of a flood control agency's unreasonable conduct, measured in light of this balancing test, constitutes no more than a reimbursement to the damaged property owners of their contribution of more than their "proper share [to] the public undertaking." 13

The second case, Locklin $v$. City of Lafayette, ${ }^{14}$ elaborated on Belair's reasonableness rule. The Locklin court rejected what it called the "arcane world of water law" theory that "if a private party had the right to inflict the damage, the government could assert the same immunity." 15 Instead, the court adopted Belair's reasonableness test in place of the earlier rule that had immunized the government on the basis of traditional property notions concerning the privilege to divert flood waters. The court in Locklin also attempted to flesh out the Belair test.

\footnotetext{
12 Id. at 1079 (citations omitted) (quotation marks omitted).

13 Id. at 1079-80 (internal citations omitted) (alteration in original).

$14 \quad 867$ P.2d 724 (Cal. 1994).

15 Id. at 746.
} 
The court identified two sets of factors. The first set, called, the Albers factors, include:

"First, the damage to th[e] property, if reasonably foreseeable, would have entitled the property owners to compensation. Second, the likelihood of public works not being engaged in because of unseen and unforeseeable possible direct physical damage to real property is remote. Third, the property owners did suffer direct physical damage to their properties as the proximate result of the work as deliberately planned and carried out. Fourth, the cost of such damage can better be absorbed, and with infinitely less hardship, by the taxpayers as a whole than by the owners of the individual parcels damaged. Fifth, ... 'the owner of the damaged property if uncompensated would contribute more than his proper share to the public undertaking.'"16

To these factors, the court added a second set drawn from Professor Arvo Van Alstyne's writings:

(1) The overall public purpose being served by the improvement project; (2) the degree to which the plaintiff's loss is offset by reciprocal benefits; (3) the availability to the public entity of feasible alternatives with lower risks; (4) the severity of the plaintiff's damage in relation to risk-bearing capabilities; (5) the extent to which damage of the kind the plaintiff sustained is generally considered as a normal risk of land ownership; and (6) the degree to which similar damage is distributed at large over other beneficiaries of the project or is peculiar only to the plaintiff. ${ }^{17}$

The Locklin court had no occasion to apply these factors because the plaintiffs had failed to show what portion of their damages were due to the actions of the defendants. 18 The California Supreme Court did, however, apply the factors in a third case, Bunch $v$. Coachella Valley Water

16 Id. at 749-50 (quoting Albers v. County of Los Angeles, 398 P.2d 129 (Cal. 1965)) (alteration in original).

$17 \quad$ Id. at 750.

18 Id. at 754 . 
District. ${ }^{19}$ The court in Bunch praised the trial judge's finding of reasonableness as being based on

a careful analysis of several factors, including the project's purpose to divert the potentially dangerous natural flow in order to prevent flood runoff from fanning out over the Magnesia Cove alluvial plain, the public need for the project, the risk of private harm, the alternatives available to reduce the risk of harm, and the District's overall fiscal and flood control responsibilities. ${ }^{20}$

The court concluded that the trial judge had appropriately balanced these factors and found the district's conduct reasonable.

What had seemed like an arcane subject then became relevant to many policymakers after the state was required to pay almost half a billion dollars in damages for a levee breach, making the case infamous among government officials and civil engineers. Paterno $v$. State of California sent shock waves through the state's flood control community and attracted attention from those in high office. ${ }^{21}$ The levee in question had been accepted by the state as part of its flood control system, but had been built earlier. The trial judge found that the levee failed due to seepage and failure of the foundation, exacerbated by the highly porous materials making up its foundation. In particular,

One of plaintiff's experts, Meehan, characterized the levee as an inferior, high-risk levee which was poorly constructed and didn't meet any engineering standards that existed any time during its life; it was built on a

19935 P.2d 796 (Cal. 1997).

20 Id. at 809-10. The court summarized the relevant evidence as follows:

Expert testimony indicated the detailed steps the District undertook to secure expert technical and engineering information on repairing its facilities and in managing those repairs represented sound engineering practice. Expert testimony was in conflict as to the engineering feasibility of the short-term solution of repairing the breach...to restore the preexisting level of flood protection, allowing the District to devote its remaining resources to developing a comprehensive flood control plan. But as the Court of Appeal observed, the trial court reasonably relied on the District's expert testimony that any attempt to "quick fix" the problem by realigning the diversion levee and lining it with stronger material would have failed during Tropical Storm Dolores.

Id. at 809.

216 Cal. Rptr. 3d 854 (Cal. App. 4th 2003). 
very unstable foundation which was subject to severe seepage pressure and offered little resistance to seepage over the course of its history; the embankment was composed of loose, sandy material and its composition and construction were not adequate. This is an indictment which the evidence supports. ${ }^{22}$

The California Court of Appeals found an ample basis for liability. Again, risk-spreading was central to its analysis, along with a sense that harm due to a defective flood control system should be internalized as part of the cost of the flood control project:

In large part our conclusion is based on the fact that the levee system benefited all of California and saved billions of dollars, and to require Paterno [the lead plaintiff] to bear the cost of the partial failure of that system - $a$ failure caused by construction and operation of an unstable levee - would violate Locklin. A basic part of the State's flood plan was to accept existing levees as much as possible, to reduce the cost of an extensive, coordinated, flood control system. The People benefited from that cost-saving feature. However, the record shows the State never tested the Linda levee, or reviewed the records of its construction, to see if it was as strong as the global plans assumed it was, and the State even ignored specific warnings about the levee's weaknesses. In such circumstance, the costs of the levee failure must be deemed part of the deferred costs of the project. ${ }^{23}$

In terms of the trial court's reasoning, the appellate court found that the Sacramento River Flood Control Plan was a sufficient basis for liability, because the plan incorporated existing levees, such as the Linda levee, and "assumed the levee met engineering standards]" despite its known substandard construction. ${ }^{24}$ In the court's view, "[T] he State

Id. at 861 .

Id. at 857.

Id. at 865 . The court described the defects graphically:

The global plans assumed the levee met engineering standards, despite the fact that the records of its construction were public and showed that mining debris was simply scraped up and heaped, without compaction, to form the Morrison Grade, which later was raised and slightly reshaped, retaining the defective core. The State claims "Linda levee as it existed after the work performed in 1934 was incorporated 
must be charged with knowledge of how the levee was built. It operated the levee for decades and had ample opportunity to examine it. If it chose not to do so for fiscal reasons, that would indicate the loss should be absorbed by the State." 25

The court then turned to a discussion of the Locklin factors. ${ }^{26}$ In light of these factors, the court found that the balance clearly weighed in favor of the plaintiff:

The public received the benefit from the levee without having to bear the expense of ensuring it met the designed standards and was capable of carrying the water channeled to it by upstream features of the project. That the levee did not break in 1955 or 1964 is either miraculous or simply indicates "third time pays for all," meaning that the earlier high water events weakened the levee but not enough to cause a failure. The savings from not correcting the problems with the levee benefited the State, and it would be unfair to require Paterno to bear all of the risk of that plan.

$\cdots$

... Like a corroding pipe buried under Santa Monica or San Diego, the Linda levee was destined to fail. Therefore, Paterno has borne the deferred costs of maintenance of the system, which costs should instead be spread to the public at large, which benefited from that system. ${ }^{27}$

Finally, the court held that the state was liable for the construction defects because it had accepted responsibility for the levee system.

into the finished 1940 work[,] in conformance with the levee design standards of the day," but although the improvements may have been designed to the standards of the day, the trial court found the levee never met those standards.

Id. (alteration in original).

25 Id. at 871. The court considered that an upgrade to the levee was an effort to improve its design capacity, and the court did not include efforts to correct defects that prevented the levee from meeting its design capacity; hence, liability was not barred by the rule against requiring the state to perform upgrades. Id. at 873-74. This is an important point. California courts recognize that it is not their proper role to decide on what kind of flood control system to construct, which involves profound tradeoffs between risk reduction and cost. Instead, the courts merely insist that the system as a general matter should live up to the performance that the state has promised the public.

26 Id. at 872-74.

27 Id. at 875-76 (citations omitted). 
"When a public entity accepts responsibility for an improvement, it becomes that entity's improvement regardless of who built it." 28

The court's approach was largely paralleled by another decision issued at roughly the same time, Arreola $v$. County of Monterey. ${ }^{29}$ The Aerrola decision suggests that knowledge of a risk is a powerful liability factor:

We conclude that in order to prove the type of governmental conduct that will support liability in inverse condemnation it is enough to show that the entity was aware of the risk posed by its public improvement and deliberately chose a course of actionor inaction - in face of that known risk..$^{30}$

Although the State of California controls the levees, it does not directly control the development of the floodplains because land use planning is primarily a function of local government. As a result of Paterno, local governments could approve unwise floodplain developments and thereby increase the state's potential liability, while facing no liability threat themselves. The California state legislature took a step toward resolving this problem with the passage of A.B. 70 in 2007.31 The statute requires a local government to

contribute its fair and reasonable share of the property damage caused by a flood to the extent that the city or

\footnotetext{
28 Id. at 876-77 (citations omitted).

29122 Cal. Rptr. 2d 38 (Cal. Ct. App. 2002). Six different complaints were filed on behalf of approximately three hundred plaintiffs as a result of flooding by the Pajaro River. Id. at 44. The plaintiffs alleged that local authorities failed to keep a channel clear, causing a levee failure. Id. They also alleged that the state had built culverts under Highway 1 that were too small to drain the flood, resulting in greater damage. Id. After some years of neglect, serious efforts were made to clear the channel in the early 1990s, but the work that was done was not enough. Id. at 48. Following a severe storm in March of 1995, there was a major flood. Id. at 49 .

Applying the Locklin factors, the court had little trouble finding the counties liable:

Knowing that failure to properly maintain the Project channel posed a significant risk of flooding, Counties nevertheless permitted the channel to deteriorate over a long period of years by failing to take effective action to overcome the fiscal, regulatory, and environmental impediments to keeping the Project channel clear. This is sufficient evidence to support the trial court's finding of a deliberate and unreasonable plan of maintenance.
}

Id. at 57. The state failed to qualify for application of the reasonableness test because its conduct would not have been privileged at common law. Id. at 62 .

$30 \quad$ Id. at 55

31 A.B. 70 adds section 8307 to the California Water Code. 
county has increased the state's exposure to liability for property damage by unreasonably approving new development in a previously undeveloped area that is protected by a state flood control project. ${ }^{32}$

There is a safe harbor provision if the local government has complied with new statutory requirements for floodplain development. ${ }^{33}$ The touchstone for liability is failure to take reasonable precautions to avoid exposing the public to risk.

\section{The Federal Scheme}

If the levee failure in New Orleans had occurred instead in levees under the control of the State of California, the victims would have a good chance of recovering for the destruction of the city. But recovering from the federal government for the destruction of New Orleans is much more difficult. ${ }^{34}$ In the case of Hurricane Katrina, it appears that the government was quite possibly at fault for failure to prevent the harm. According to some experts, the federal government was negligent in its

32 CAL. WATER CODE $\$ 8307$ (a) (West Supp. 2009). Under the code section, “'Unreasonably approving' means approving a new development project without appropriately considering significant risks of flooding made known to the approving agency as of the time of approval and without taking reasonable and feasible action to mitigate the potential property damage to the new development resulting from a flood." Id. $\S 8307(\mathrm{c})(3)$.

31 Id. $\S 8307$ (a). Under section 8307 (b), the local government's duty of contribution is triggered only if the state has been sued for damages. For an argument for expanded liability of local governments for unsafe development, see Timothy Kzolowski, Dams and Levees Are Not Enough: The Case for Recognizing a Cause of Action Against Non-Complying NFIP Communities, 32 WM. \& MARY ENVTL. L. \& POL'Y REV. 245 (2007).

34 In theory, recovery against the State of Louisiana would be another option, but it seems unlikely to say the least that the state has the financial resources to provide compensation on a large scale. In addition, state law creates some obstacles to recovery. Compare Bernard v. Thigpen Constr. Co., 702 So. 2d 1387 (La. 1997), with Bernard v. Thigpen Constr. Co., 695 So. 2d 518 (La. Ct. App. 1997), vacated by 702 So. 2d 1387 (La. 1997). The appellate court had approved certification of the class injured in the 1995 flood, but then the Louisiana Supreme Court set aside the certification after ruling in another decision that "the existence of individual causation and liability issues as to each potential class member may so predominate over common issues that class certification is inappropriate." Bernard, 702 So.2d at 1387 . The appellate opinion is more interesting in imagining how plaintiffs could come together as a class following a natural disaster. Louisiana's prescription period under La. R.S. 9:5624 may bar recovery because some causes of action may have already expired long before the flood took place. See John J. Costonis, Avenal v. State: Takings and Damagings in Louisiana, 65 LA. L. REV. 1015 (2005) for further discussion on this point. 
construction of the New Orleans flood control system, ${ }^{35}$ or at least, it is clear that the levees did not perform as designed. ${ }^{36}$

The federal government is generally liable for negligence under the Federal Tort Claims Act, but only if the negligence relates to the implementation of a project rather than the basic policy decisions involved in planning. Moreover, the federal government enjoys especially broad statutory immunity for damages caused by flooding.

The Flood Control Act of $1928^{37}$ provides that "[n]o liability of any kind shall attach to or rest upon the United States for any damage from or by floods or flood waters at any place[.]"38 The Act was passed as part of a congressional response to the great Mississippi flood of 1927. Congress decided for the first time that the federal government should play a major part in flood control, which had previously been seen as a state and local responsibility. The goal of the Act appears to have been

35 For a discussion of these issues, see Daniel A. Farber, et. al, Reinventing Flood Control, 81 TUL. L. REv. 1085 (2007), also available at http://www.law.berkeley.edu/library/disasters /Farber_et_al.pdf. For present purposes, I will ignore the possibility that climate change contributed to Hurricane Katrina, and hence to the harm, because of the severe and possibly intractable problems of proof.

36 An important example of the potential for negligence claims is the failure of the 17th Street drainage canal floodwall in New Orleans. Based on video recordings, reports by residents, and tests of the evolution of the failure, a National Science Foundation research team was able to reconstruct what happened early in the morning of August 29, 2005. Winds blew over the large oak trees growing near the top of the levees that should never have been allowed to grow there. The trees' root balls ripped out significant parts of the levee toe connected with underground seepage, a defect which also should have been corrected earlier. A vertical joint opened up at the joint between two sections; the joint should not have been weaker than the segments it connected. At this point, a deep breach opened. As the water continued to rise, the walls leaned, opening more breaches. In the end, the levee, floodwall, and supporting sheet pile were displaced laterally toward nearby homes by more than forty-five feet.

The fundamental flaw was that the levee was built on unstable soil. Examination of early maps of the area revealed that bayou tributaries had crossed the canal at the point of failure. These tributaries were filled with very soft soil that was buried by landfill before the levee was built. The Army Corps of Engineers did not use sufficient boring samples to detect the variations in soil stability. Further, the Corps built the levee to a very minimum standard of safety (1.3) on experience with rural rather than urban topography - that is, use of a design strength 1.3 times greater than the maximum expected loading. This margin of safety was too small given the high human and economic costs of a levee failure in New Orleans. And there were other flaws. Field tests performed in 1965 should have warned the Corps that the levee itself was having a dangerous effect on underlying soil strengths. Even earlier, geologic tests performed by the Corps indicated the treacherous nature of the soil conditions. And the tops of the floodwalls were almost two feet lower than projected because of subsidence. Even when surveys in 2004 clearly showed that the floodwalls were not high enough, no corrective action was taken. Thus, the design was not based on best available information.

37 Flood Control Act of 1928, Pub. L. No. 70-391, 45 Stat. 534-39 (1928).

$38 \quad 33$ U.S.C. $\$ 702 c(2000)$. 
to limit the federal government's financial exposure to the direct cost of the flood control project. In United States $v$. James, ${ }^{39}$ the United States Supreme Court rejected arguments that the provision was limited to immunity for property damage and instead emphasized the broad scope of the statutory language.

This immunity will probably prevent victims of Katrina from recovering damages from the federal government.40 However, there may be some exceptions. One important trial court ruling, In re Katrina Canal Breaches Consolidated Litigation, allows a suit to go forward.41 In the case, the plaintiffs claimed that the harm was caused by a navigation project (the Mississippi River Gulf Outlet canal, commonly known as "MR GO") rather than a flood control project. The plaintiffs' lawyers clearly face an uphill battle. Nevertheless, if the MR GO case is successful, the plaintiffs could recover billions of dollars.

There is room for considerable debate about whether the failure of the flood control system was the fault of the federal government, and the degree to which similar damages would have occurred even if the system had met its design standards. Victims who have suffered property damage do receive other kinds of assistance from the federal government, particularly from the Federal Emergency Management Agency ("FEMA"). The families of those who died in the flood received nothing from the federal government unless they happened to have social security survivor's benefits. If the MR GO litigation proceeds, at least some survivors and property owners may receive recompenseand the benefit of a full, objective investigation into the causes of their losses.

\footnotetext{
$39 \quad 478$ U.S. 597 (1986).

40 As an illustration of the scope of immunity, consider Mocklin v. Orleans Levee District, 877 F.2d 427 (5th Cir. 1989). The plaintiffs brought suit against several defendants, including the Army Corps of Engineers, for the wrongful death of their son and sought damages under the Federal Torts Claim Act. Id. at 428 . The child had drowned when he slipped from a sand bar caused by the dredging into one of the flotation channels used to prevent further flood damage; the Corps had dredged the lake (Lake Pontchartrain) to make flotation channels during the construction phase of levees. Id. The government's defense relied on \$702c. Id. at 428-29. The Court concluded that the child died "from or by" "flood water" within the meaning of the FCA because the flotation channel where the plaintiffs' son died contained water related to flood control; the flood channels were "inescapably" part of the flood control project. Id. at 429-30.

41 In re Katrina Canal Breaches Consolidated Litigation, 471 F. Supp. 2d 684 (E.D. La. 2007).
} 


\section{B. Climate Change}

Whether excessive emitters of greenhouse gases will be required to compensate for the harm caused by climate change is unclear. What is clear is that such claims will be raised in a variety of forums.

The existence of damage has now become nearly incontestable. We are already faced with a number of adverse impacts from climate change.

\section{Examples of observed changes caused by human releases of GHG [greenhouse gases] include shrinkage of glaciers, thawing of permafrost, later freezing and earlier break-up of ice on rivers and lakes, lengthening of mid- to high-latitude growing seasons, poleward and altitudinal shifts of plants and animal ranges, declines of some plant and animal populations, and earlier flowering of trees, emerging of insects, and egg-laying in birds. 42}

Sea level rise is one of the most predictable consequences of climate change. ${ }^{43}$ Apart from the unknown contribution of glacial melting from Greenland and Antarctica, ${ }^{44}$ the simple change in temperature of the oceans will contribute to thermal expansion, just as increased temperature causes the mercury in a thermometer to rise. 45 As the Intergovernmental Panel on Climate Change ("IPCC") explains, "Observations since 1961 show that the average temperature of the global ocean has increased to depths of at least $3000 \mathrm{~m}$ and that the ocean

42 Donald A. Brown, The U.S. Performance in Achieving Its 1992 Earth Summit Global Warming Commitments, 32 ENVT'L. L. REP. 10741, 10756 (2002) (footnote omitted).

43 See, e.g., K. Hasselman, et al., The Challenge of Long-Term Climate Change, 302 SCIENCE 1923, 1924 (2003) (Figure 2) (predicting a two meter increase in sea level under a "businessas-usual" scenario by 2100 , but only twenty centimeters under an optimum regulatory strategy). The effects of sea level rise are discussed in more detail in Susanne C. Moser, Climate Change and Sea-Level Rise in Maine and Hawai'i: The Changing Tides of an Issue Domain, in RONALD B. MICHELL, ET AL., GLOBAL ENVIRONMENTAL ASSESSMENT (2006).

44 The IPCC states simply that "[d]ynamical processes related to ice flow not included in current models but suggested by recent observations could increase the vulnerability of the ice sheets to warming, increasing future sea level rise. Understanding of these processes is limited and there is no consensus on their magnitude." Contribution of Working Group I to the Fourth Assessment Intergovernmental Panel on Climate Change, Climate Change 2007: The Physical Science Summary for Policymakers, 17 (2007). However, the IPCC also reports that uncontrolled warming could result in sea level rises of up to seven meters (about twenty four feet) from the melting of the Greenland ice sheet alone. Id.

45 Changes in ocean temperature will also affect fish stocks. See Hans O. Portner \& Rainer Knust, Climate Change Affects Marine Fishes Through the Oxygen Limitation of Thermal Toleration, 315 SCI. MAG. 95 (2007). 
has been absorbing more than $80 \%$ of the heat added to the climate system. Such warming causes seawater to expand, contributing to sea level rise." 46 Moreover, IPCC reports that "[m]ountain glaciers and snow cover have declined on average in both hemispheres. Widespread decreases in glaciers and ice caps have contributed to sea level rise (ice caps do not include contributions from the Greenland and Antarctic Ice Sheets)." 47

These and other harmful effects have provided fodder for litigation. Climate change litigation of various kinds is clearly on the rise, and the trend is to hold that potential damage from climate change is a legally cognizable injury. ${ }^{48}$ Although the favorable decisions have involved standing issues or judicial review of administrative actions rather than damage suits, scholars have begun earnestly to discuss the damage issues. $^{49}$

A case filed by the State of California against General Motors Corporation illustrates the potential for damage litigation. ${ }^{50}$ In an action

46 IPCC, supra note 45 , at 5 .
47 Id.

48 See Massachusetts v. EPA, 549 U.S. 497 (2007); In re Quantification of Envtrl. Costs, 578 N.W. 2d 794, 796-97 (Minn. Ct. App. 1998) (upholding agency's quantification of harm from CO2). See Gbemre v. Shell Petroleum, Federal High Court, Benin, November 14, 2005, Unreported Suit No. FHC/B/CS/53/05, available at http://www.climatelaw.org/cases/ case-documents/nigeria/ni-shell-nov05-judgment.pdf (condemning natural gas flaring in Nigeria); Australian Conserv. Found. v. Minister for Planning, [2004] VCAT 2029, available at http://www.austlii.edu.au/au/cases/vic/VCAT/2004/2029.html (stating at the international level that greenhouse emissions must be taken into account in planning decisions). Section 601 of the Restatement (Third) of Foreign Relations Law states that a nation "is obligated to take such measures as may be necessary, to the extent practicable under the circumstances, to ensure tbat [sic] activities within its jurisdiction or control ... are conducted so as not to cause significant injury to the environment of another state ..." This principle is based on the famous Trail Smelter decision. Trail Smelter (U.S. v. Canada), 3 R.I.A.A. 1938, 1965 (1941) (making reference to United States federal common law. For discussion of the international litigation, see Michael G. Faure \& Andre Nollkaemper, International Liability as an Instrument to Prevent and Compensate for Climate Change, 43 STAN. J. INT'L L. 123 (2007). A critique of efforts to use the Alien Torts Act as a basis for climate change liability can be found in Eric A. Posner, Climate Change and International Human Rights Litigation: A Critical Appraisal, 155 U. PA. L. REV. 1955 (2007).

49 See Angela Lipanovich, Smoke Before Oil: Modeling a Suit Against the Auto and Oil Industry on the Tobacco Tort Litigation is Feasible, 35 GOLDEN GATE U. L. REV. 429 (2005); Hari M. Osofsky, The Geography of Climate Change Litigation: Implications for Transnational Regulatory Governance, 83 WASH. U. L.Q. 1789 (2005); Vincent S. Oleszkeiwicz \& Douglas B. Sanders, The Advent of Climate Change Litigation Against Corporate Defendants, 27 INT'L ENVTL. REP. 936 (2004).

50 Complaint for Damages and Declaratory Judgment, California v. General Motors Corp., 2006 WL. 2726547, C06-05755 (N.D. Cal.) (filed Sep. 20, 2006). As discussed below, the suit has been dismissed and is now pending on appeal. It should be noted that climate change may breed other kinds of damage litigation. For example, if carbon sequestration technology becomes widespread and carbon dioxide releases take place, there could well 
filed in federal district court against leading automobile manufacturers, the state alleges two causes of action for public nuisance, one under federal common law and one under California law. The complaint focuses on several key examples of damages. First, the state allegedly will be required to spend large sums of money on studies and infrastructure changes to its water systems. The Sierra Nevada snow pack, which is the source of much of California's water, has allegedly been shrinking. This decrease in snow pack is likely to increase flooding and interfere with the state's water system. Preventing flooding and assuring a reliable water supply will require major financial investments by the state. Second, rising sea levels will cause increased beach erosion and increased salt infiltration into the Sacramento Bay-Delta, which will then require increased expenditures to protect the eco-system and the water supply for much of the state. Third, climate change is impacting extreme heat events, increasing the risk of injury or death (especially to the elderly). Finally, the complaint alleges that

[d]ozens of other impacts have begun or are anticipated with a high level of certainty, including increased risk and intensity of wildfires, risk of prolonged heat waves, loss of moisture due to earlier snow pack melt and related impacts on forests and other ecosystems, and a change in ocean ecology as water warms." 51

The complaint adds that "[a]ll of these impacts are the subject of State study and planning, which costs the State millions of dollars." 52 Consequently, California requests that the defendants be held jointly and severally liable for monetary damages. ${ }^{53}$

For the moment, however, much of the litigation seems to be stymied. At present, California v. General Motors Corp. and a similar

be litigation by injured parties. For a discussion of the issues, see Alexandra B. Klass \& Elizabeth J. Wilson, Climate Change and Caron Sequestration: Assessing a Liability Regime for Long-Term Storage of Carbon Dioxide (March 2008) (on file with the author), available at http://works.bepress.com/cgi/ viewcontent.cgi?article=1003\&context=alexandra_klass.

51 Complaint, supra note 50, at I 56.

$52 \quad$ Id.

53 Id. at "RELIEF REQUESTED[]" ๆ 1 1-2. The complaint also requests declaratory relief as well as attorney's fees. The complaint in similar litigation filed against public utilities can be found at 2004 U.S. Ct. Pleadings LEWIX 1910 (July 21, 2004). In terms of injuries, the complaint alleges rising temperatures ( $(104)$, declining snowfall in New England ( $(105)$, growing pubic health threats from increased temperatures (II 110-11), damage to coastal resources (19 112-17), and damage to water supplies (9 118-20). In the Midwest, the complaint alleges damage to the Great Lakes ( 9 121-27), damage to agriculture (\$ף 12831), and more generally, harm to the states' ecology, natural resources, and exposure to the risk of abrupt climate change ( $($ ป 132-46). 
lawsuit against electrical utilities are pending on appeal after the district courts ruled that the political question doctrine precluded the litigation..$^{54}$ This application of the political question doctrine seems dubious.

Under current doctrine, the political question argument seems untenable. Baker $v$. Carr 55 limits the political question doctrine to cases in which there is a textually demonstrable commitment of an issue to another branch of government, judicially manageable standards do not exist, or the nation needs to speak with a single voice. ${ }^{56}$ None of these

54 See Conn. v. Am. Elec. Co., 406 F. Supp. 2d 265 (S.D.N.Y. 2005). See also Cal. v. General Motors Corp., Cause No. 2006 WL 2726547 (N.D. Cal. Sept. 17, 2007). Reliance on the political question doctrine seems misplaced here, given the narrow scope of that doctrine as defined by the Supreme Court. On the other hand, a similar public nuisance suit was allowed to go forward in North Carolina o. TVA, 439 F. Supp. 2d 486 (W.D.N.C. 2006). Although the TVA court did not directly consider the political question doctrine, TVA did invoke separation of powers concerns, and parts of the court's discussion speak to the political question issue:

The appropriate level of pollution emissions is a matter, not for only one or two Branches, but rather for all three Branches of government. See, e.g., 42 U.S.C. \$\$ 7401-7431 (Sub-chapter 1, Part A of the Clean Air Act, wherein Congress sets forth "air quality and emissions limitations"); 40 C.F.R. $\$ \$ 50.1-50.12$ (wherein the Environmental Protection Agency sets forth "national primary and secondary ambient air quality standards"); Her Majesty the Queen in Right of the Province of Ontario v. City of Detroit, 874 F.2d 332, 343 (6th Cir.1989) (discussing the role of the courts in controlling air pollution). As the Supreme Court described it, air pollution "is, of course, one of the most notorious types of public nuisance in modern experience." Washington v. General Motors Corp., 406 U.S. 109, 114, 92 S.Ct. 1396, 31 L.Ed.2d 727 (1972). The interdependence of the Branches necessary to control and reduce this national threat is certainly not repugnant to the Constitution, and refusing to allow TVA to make unlimited emissions decisions under the protection of a discretionary function exemption would not place the Judicial Branch in the position of performing tasks more properly accomplished by other Branches.

TVA, 439 F. Supp. $2 d$ at 495.

55369 U.S. 186 (1962).

56 Baker actually subdivides some of these factors, resulting in a disjunctive list of six:

1. "a textually demonstrable constitutional commitment of the issue to a coordinate political department;"

2. "a lack of judicially discoverable and manageable standards for resolving [the issue];"

3. "the impossibility of deciding without an initial policy determination of a kind clearly for nonjudicial discretion;"

4. "the impossibility of a court's undertaking independent resolution without expressing lack of the respect due coordinate branches of government;"

5. "an unusual need for unquestioning adherence to a political decision already made;"

6. "the potentiality of embarrassment from multifarious pronouncements by various departments on one question." 
factors seem to be present in either case. Courts customarily hear nuisance cases, so obviously there is no textual constitutional commitment of such issues to another branch of government, nor is there a lack of sufficient judicial standards in a nuisance case to satisfy Article III of the Constitution. As to whether the nation needs to speak with a single voice, the Supreme Court rejected that argument in considering a statutory climate change issue and finding foreign policy concerns beside the point. ${ }^{57}$ What makes the climate change nuisance cases different from garden-variety nuisance cases is merely that the potential liability and societal implications are very large.

It was probably scale of the climate change issue that made these two district judges frantically reach out to the political question doctrine as a way of dodging the litigation. The district courts' concern seemed to be about the magnitude of the issue of climate change and the potential repercussions of a ruling for society as a whole..$^{58}$ But the Supreme Court has never found the magnitude of the remedy or the societal impact of a case to be reasons for holding it non-justiciable, and the Court clearly considers at least some aspects of climate change to be justiciable. 59 Of course, in the end, five Justices can rule however they wish on how to define the political question doctrine, but in the meantime, existing doctrine provides little basis for dismissing the suits.

Assuming the suits are held to be justiciable, the plaintiffs will still face major hurdles. ${ }^{60}$ Among the challenges are potential statutory

Id. at 217. In the text, I have packaged 2 and 4 together as variants of the manageable standards factors, and 3,5, and 6 as involving the need for the nation to speak with one voice.

57 See Massachusetts v. EPA, 549 U.S. 497, 534 (2007) (considering a statutory climate change issue, and finding foreign policy concerns beside the point).

58 For example, in the California case, the district court cited the global implications of the issue:

Plaintiff has failed to provide the Court with sufficient explanation or legal support as to how this Court could impose damages against the Defendant automakers without unreasonably encroaching into the global warming issues currently under consideration by the political branches. Because a comprehensive global warming solution must be achieved by a broad array of domestic and intemational measures that are yet undefined, it would be premature and inappropriate for this Court to wade into this type of policy-making determination before the elected branches have done so.

General Motors Corp., 2007 WL 2726871 at ' 10.

59 In Massachusetts $v$. EPA, the Court held that the plaintiffs had standing to sue the federal government on a statutory issue relating to climate change, and the Court ruled in the plaintiffs' favor on the merits. 549 U.S. 497 (2007).

60 For analysis of the liability issues, see Bradford C. Monk, Civil Remedies, in Michael B. Gerrard, Global Climate and U.S. Law 183, 200-13 (2007); Kenneth B. Alex, California's Global Warming Lawsuit: The Case for Damages, in CREATIVE STRATEGIES FOR PROTECTING THE 
preemption arguments, defining the standard of care and the recipient of the duty, 61 and proof of causation and damages. These questions are difficult, but not necessarily insurmountable if science fills some of the gaps in the plaintiffs' cases.

The proof issues in climate tort litigation may be susceptible to scientific evidence, if not now, then soon. It is difficult to link specific harmful events to climate change, which is why we will probably never know whether Hurricane Katrina was an effect of climate change. But at least in some instances, the fingerprint of climate change may be more discernible.

An important, if not shocking, example of the effects of climate change is provided by a recent European heat wave. A heat wave in 2003 caused over ten billion dollars in economic losses and up to 35,000 deaths in Europe. ${ }^{62}$ The scientific evidence now seems to establish by at least a preponderance of the evidence that these deaths were due to climate change. Scientists estimate that climate change increased the odds of such an event by a factor of four to ten over the "base rate."63 The IPCC has also concluded that "the excess deaths of the 2003 heatwave in Europe are likely to be linked to climate change." 64 Thus, it seems quite possible to tie at least some specific adverse effects to climate change with considerable confidence. ${ }^{65}$ Clearly, additional problems remain, ${ }^{66}$ in particular, deciding how to allocate responsibility among a large number of greenhouse gas emitters. But that problem is not necessarily unsolvable. ${ }^{67}$

ENVIRONMENT (Clifford Rechtschaffen \& Denis Antolini eds., 2007) (Alex heads the state of California's climate litigation team).

61 On this issue, see David Hunter \& James Salzman, Negligence in the Air: The Duty of Care in Climate Change Litigation, 155 U. PA. L. REV. 1741 (2007).

62 See Myles Allen et al., Scientific Challenges in the Attribution of Harm to Human Influence on Climate, 155 U. PA. L. REV. 1353, 1388-89, 1398 (2007).

$63 \quad$ Id. at 1392.

64 Ulisses Confalonieri, Human Health, Climate Change 2007: Impacts, Adaptability and Vulnerability. Contribution of Working Group II to the Fourth Assessment Report of the Intergovernmental Panel on Climate Change 307 (2007). For further discussion of heat waves and climate change, see Ann E. Carlson, Heat Waves, Global Warming \& Mitigation, in IsSUES IN LEGAL SCHOLARSHIP, CATASTROPHIC RISKS: PREVENTION, COMPENSATION, AND RECOVERY (2007): Article7, available at http://www.bepress.com/ils/iss10/art7.

65 If a negligence standard is applied, it would also be necessary to show that if greenhouse emissions had been kept to reasonable levels, the heat wave would not have occurred. Current scientific analysis does not seem to have addressed this point, but it seems feasible to do so.

66 Problems include determination of the standard of liability and various preemption arguments that may prevent the courts from reaching the merits.

67 For some thoughts about cost allocation, see Daniel A. Farber, Apportioning Climate Change Costs, 26 UCLA J. ENVTL. L. \& POL'Y (2007). 
The district judges who found the issue to be a political question were worried about the manageability of the litigation and its potential for expansive social impacts. It is not hard to imagine that these concerns might resurface again in different doctrinal guise if courts are ultimately faced with the merits issues, perhaps in the form of rulings that carbon dioxide emitters do not owe a duty of care toward the victims of climate change. Climate change is a very long-term problem, and it seems unlikely that the liability issues will be definitively settled for some time, regardless of the outcome of the present litigation.

\section{Large Scale Environmental Contamination and Toxics Exposures}

Courts have also been confronted with difficult problems of causation and long time lags in cases involving widespread contamination issues. ${ }^{68}$ These cases demonstrate some lessons for catastrophic torts more generally.

\section{The Proximate Cause Problem and Medical Monitoring}

In many situations involving toxics exposures, the biggest barrier to tort recovery is proof of causation. Even when a general link between a disease and exposure to a substance has been established, it may be difficult to show that a particular individual's disease was caused by exposure to that specific substance:

Specific causation requires a plaintiff to prove by a preponderance of the evidence that the defendant caused that particular plaintiff's harm. Many courts interpret the preponderance standard to require a relative risk ratio of 2.0 or greater-for example, a defendant's conduct more than doubled the plaintiff's risk of injury.... Thus, if an epidemiological study indicates that exposure to a particular substance increases the incidence of a disease among those exposed by only forty percent, then a court will probably find that the plaintiff has failed to meet the burden of

\footnotetext{
68 Despite these difficulties, plaintiffs have had some degree of success, as exemplified in a 2004 settlement in which Dupont paid $\$ 340$ million to settle a class action, including $\$ 235$ million in medical monitoring expenses. See Thomas O. McGarity, The Complementary Roles of Common Law Courts and Federal Agencies in Producing and Using Policy-Relevant Scientific Information, 36 ENVTL. L. 1026, 1045 (2007).
} 
proving specific causation unless more direct evidence is offered. ${ }^{69}$

There is considerable scholarly support for a different approach to probabilistic harm. Rather than providing full compensation for victims whose probability of causation is over fifty percent and none for those who fall under this threshold, this approach would provide proportional recovery to all victims. ${ }^{70}$ Thus, if there is a sixty percent chance that a victim's injury was caused by exposure to the toxic chemical, the victim would receive compensation for sixty percent of her damages. Similarly, if the victim had only a twenty percent likelihood of causation, twenty percent of the damages would be compensable. However, courts have not seemed to follow the lead of those commentators who have suggested proportional recovery. ${ }^{71}$

It may sometimes be possible to prove specific causation, particularly when a toxic substance greatly increases the background risk of a disease. An additional problem though is that even when a plaintiff is known to be at risk, diseases such as cancer may have long latency periods. Courts have provided some limited relief to these at-risk plaintiffs in the form of compensation for the expense of medical monitoring.

The prevailing approach to medical monitoring is illustrated by In re Paoli R.R. Yard PCB Litigation. ${ }^{72}$ The Third Circuit held that a medical monitoring claimant must prove four elements: (1) that she was significantly exposed to a proven hazardous substance through the

69 Albert C. Lin, Beyond Tort: Compensating Victims of Environmental Toxic Injury, $78 \mathrm{~S}$. CAL. L. REv. 1439, 1449-50 (2005) (footnotes omitted). For further discussion on this issue, see Restatement Third of Torts: Liability for Physical Harm \$28 cmt. B, rep. Note (Proposed Final Draft No. 1 April 6, 2005).

70 See, e.g., David Rosenberg, The Causal Connection in Mass Exposure Cases: A "Public Law" Vision of the Tort System, 97 HARV. L. REv. 849 (1984); William Landes \& Richard Posner, Tort Law as a Regulatory Regime for Catastrophic Personal Injuries, 13 J. LEG. STUD. 417 (1984); Richard Delgado, Beyond Sindell: Relation of Cause of Cause-in-Fact Rules for Indeterminate Plaintiffs, 70 CAL. L. REV. 881 (1982).

71 One way of recovering for what amounts to a risk of future harm takes the form of stigma damages to property, where the possibility that exposures will be dangerous allegedly becomes translated into the value of the property. See Dealers Mfg. Co.v. County of Anoka, 615 N.W.2d 76 (Minn. 2000) (allowing stigma damages for property that is merely close to contaminated property); Chance v. BP Chemicals, 670 N.E.2d 985 (Ohio 1996) (requiring some type of physical damage or interference with use as a predicate for stigma damages).

$72 \quad 916$ F.2d 829 (3d Cir. 1990), affd 35 F.3d 717, 784-88 (3d Cir. 1994). A useful analysis of this remedy can be found in Kenneth S. Abraham, Liability for Medical Monitoring and the Problem of Limits, 88 VA. L. REV. 1975 (2002). Abraham points out that the duty to pay for medical monitoring can be seen as akin to the duty to rescue a person whom the defendant has tortuously placed in danger. Id. at 2002. 
defendant's negligence; (2) that as a proximate result she suffers an increased risk of contracting a serious latent disease; (3) that the increased risk makes medical examinations reasonably necessary; and (4) early detection and treatment of the disease is possible. In most medical monitoring cases, plaintiffs have sought or courts have awarded traditional common-law lump-sum damages. In a few toxic exposure cases, however, litigants have pursued, or courts have expressed their preference for, periodic payment of future medical surveillance expenses out of a court-supervised trust fund or similar mechanism..$^{73}$

The Supreme Court dealt with medical surveillance liability a decade ago in Metro-North Commuter R.R. Co. v. Buckley,74 a case arising under the Federal Employers' Liability Act ("FELA"). ${ }^{75}$ The plaintiff had been exposed to asbestos as a pipe fitter while working for the railroad. After he learned that he faced an increase risk of cancer, he sought to recover damages for the resulting emotional distress and a lump-sum recovery for future medical check-ups. The Court noted a number of general concerns about allowing recovery for medical monitoring not connected with any existing injury, including the potentially wide scope of liability, the lower priority of claimants with monitoring costs versus those with already realized injury, the difficulty of identifying what extra monitoring is warranted by an exposure, and the possibility that monitoring expenses would be covered by health insurance or some other source. The Court's observations suggest some unease with medical monitoring damages in general. Ultimately, however, the Court's holding was narrow and rejected only what it considered to be a very broad rule of recovery of lump-sum damages:

We have not tried to balance these, or other, competing considerations here. We point them out to help explain why we consider the limitations and cautions to be important-and integral-parts of the state-court decisions that permit asymptomatic plaintiffs a separate tort claim for medical monitoring costs. That being so, we do not find sufficient support in the common law for the unqualified rule of lump-sum damages recovery that is, at least arguably, before us here. And given the mix of competing general policy

73 See Amy B. Blumenberg, Medical Monitoring Funds: The Periodic Payment of Future Medical Surveillance Expenses in Toxic Exposure Litigation, 43 HASTINGS L.J. 661 (1992). The leading case on medical surveillance is Ayers $v$. Township of Jackson, 525 A.2d 287 (N.J. 1987). 74521 U.S. 424 (1997).

75 Employers' Liability Acts (Federal Employers' Liability Act) (FELA), 45 U.S.C. § 51-60 (2007). 
considerations, plaintiff's policy-based arguments do not convince us that the FELA contains a tort liability rule of that unqualified kind.

This limited conclusion disposes of the matter before us. We need not, and do not, express any view here about the extent to which the FELA might, or might not, accommodate medical cost recovery rules more finely tailored than the rule we have considered. ${ }^{76}$

Unfortunately, a few state courts seem to have misinterpreted this limited holding as a broad rejection of medical monitoring expenses. ${ }^{77}$ In any event, this and other cases indicate that the Supreme Court is unlikely to be on the cutting edge of expanding tort liability.

Medical monitoring is a form of preventive action, and some courts have used public nuisance law to provide compensation for the expenses of other kinds of preventive measures. One example is lead paint, a widespread form of environmental contamination that poses special risks to young children. The use of lead paint in housing was prohibited in 1978, but 24 million housing units still contain the paint and its resulting lead dust. ${ }^{78}$ In the past decade, state and local governments have had some successes in public nuisance suits against the lead paint

76 Metro-North Commuter R.R. Co., 521 U.S. at 444. The Court's lack of sympathy to tort plaintiffs is fairly palpable here - not the willingness to dispose of the case on a ground that the court says is only "arguably present" in the case before it. In addition, as the dissent pointed out, the majority's discussion is extremely muddled:

It is not apparent why (or even whether) the Court reverses the Second Circuit's determination on Buckley's second claim. The Court of Appeals held that a medical monitoring claim is solidly grounded, and this Court does not hold otherwise. Hypothesizing that Buckley demands lump-sum damages and nothing else, the Court ruminates on the appropriate remedy without answering the anterior question: Does the plaintiff have a claim for relief? Buckley has shown that Metro-North negligently exposed him to "extremely high levels of asbestos," 79 F.3d, at 1341, and that this exposure warrants "medical monitoring in order to detect and treat [asbestos-related] diseases as they may arise." Id., at 1346. Buckley's expert medical witness estimated the annual costs of proper monitoring at $\$ 950$. Ibid. We do not know from the Court's opinion what more a plaintiff must show to qualify for relief.

Id. at 448 (Ginsburg, J., dissenting in part and concurring in the judgment) (citation omitted) (footnote omitted).

7 See Jamie A. Grodsky, Genomics and Toxic Torts: Dismantling the Risk-Injury Divide, 50 STAN. L. REV. 1671, 1712 (2007).

78 See Katie J. Zoglin, Getting the Lead Out: The Potential of Public Nuisance in Lead-Based Paint Litigation, in CREATIVE STRATEGIES FOR PROTECTING THE ENVIRONMENT, 340-42. 
manufacturers. ${ }^{79}$ In Rhode Island $v$. Lead Industries Ass' $n$, after the trial court upheld a public nuisance claim, one defendant settled for almost twelve million dollars, and the others were eventually found liable for abatement costs (possibly in the one billion dollar range) after a jury trial. ${ }^{80}$ The Wisconsin Court of Appeals also allowed a suit to go forward despite the plaintiff's inability to identify the source of the paint for particular houses. ${ }^{81}$

Most recently, the California Court of Appeals upheld public nuisance claims against the lead-based paint industry. ${ }^{82}$ The court held that a private class action for damages was foreclosed as being essentially a products liability case in disguise, but that the government's action for abatement of the nuisance could proceed. Relying on the California lead paint case, County of Santa Clara, as well as other authorities, a New York federal district court upheld public nuisance claims against manufacturers of methyl tertiary-butyl ether (MBTE), a gasoline fuel additive. ${ }^{83}$ Summarizing California law, the district court said:

While it is true that "the law of nuisance is not intended to serve as a surrogate for ordinary products liability," California courts have allowed nuisance claims to proceed where the manufacturer's or distributor's actions have "created or assisted in the creation of the nuisance." Such actions, however, must amount to more than simply the manufacture or distribution of the defective product-rather, a defendant must take other "affirmative acts" that contribute "directly" to the nuisance. Importantly, a failure to warn regarding the dangers of a product, without more "activity directly connected" to the creation of the nuisance, is an insufficient basis for nuisance liability. But where a defendant engages in more substantial conduct

\footnotetext{
79 In New York, there has been successful litigation premised on the theory that the manufacturers engaged in deceptive marketing regarding the safety of the paint. See City of New York v. Lead Indus. Ass'n, 660 N.Y.S. 2d 422 (App. Div. 1997).

80 Zoglin, supra note 78, at 350-54.

81 City of Milwaukee v. NL Indust., Inc., 691 N.W. 2d 888 (Wis. Ct. App. 2004). Quoting and endorsing the city's argument, the court's definition of public nuisance included three elements plus public policy: "(1) harm occurred to the public; (2) defendants were a substantial factor in causing the harm; and (3) abatement of the cause of the harm was reasonable." Id. at 892.

82 County of Santa Clara v. Atlantic-Richfield Co., 40 Cal. Rptr. $3 d 313$ (2004).

83 In re Methyl Tertiary Butyl Ester (MTBE) Products, 457 F. Supp. 2d 455 (S.D.N.Y. 2006).
} 
contributing to the nuisance, liability may well be appropriate. ${ }^{84}$

The district court then concluded that active promotion of the product satisfied the requirement for public nuisance liability. Note that the remedy in these cases is clean-up-not an award of damages for harm caused to children who are exposed to the paint.

As the examples of medical monitoring and lead paint clean-up indicate, remedial innovation is one way to deal with the issues posed by major risks. An analogy in the climate change area would be to provide compensation for adaptation expenses or, more narrowly, for monitoring and forecasting the local impacts of climate change. ${ }^{85}$

\section{Oil Spills}

Another facet of catastrophic risk litigation is presented by litigation for oil spills. Oil spill litigation is less likely to turn on causation-infact-the damage is often immediate and unmistakable-than on proximate cause (or alternatively, the existence of a duty toward the plaintiffs). For instance, in Benefiel $v$. Exxon Corp. ${ }^{86}$ the plaintiffs were consumers who alleged that the Exxon Valdez oil spill had resulted in higher oil prices. The flaw in their claim was the existence of intervening causes:

In this case, the spill itself did not directly cause any injury to the appellants. Rather, plaintiffs alleged the spill triggered a series of intervening events, including the decision of the United States Coast Guard to close the Port of Valdez to facilitate clean-up efforts; the alleged decision by refineries in the western United States to raise prices rather than to use their own oil reserves to make up any shortage; and the decision of wholesalers, distributors and retailers to pass on these price increases. ${ }^{87}$

The Benefiel court concluded that the "plaintiffs themselves alleged the existence of at least one intervening act causing the price hike: the

\footnotetext{
84 Id. at 463-64 (footnotes omitted).

85 For an argument that these costs are an appropriate basis for compensation, see Daniel A. Farber, Basic Compensation for Victims of Climate Change, 155 U. PA. L. REV. 1605 (2007).

B6 959 F.2d 805 (9th Cir.1992).

$87 \quad$ Id. at 807 .
} 
alleged decision of California oil refiners to exploit the supposed shortage." 88

Benefiel was only one piece of the massive litigation arising out of the Exxon Valdez spill, however. ${ }^{99}$ More than a hundred law firms were involved in over two hundred suits, involving more than thirty thousand claims. The total damage claims exceeded fifty billion dollars. Although some of these claims were settled or dismissed, more than ten thousand remained. Some of these claims were foreclosed by the rule of Robins Dry Dock \& Repair Co. $v$. Flint, 90 which requires that a person must suffer direct physical harm in order to recover economic losses. On the other hand, there is a recognized exception to Robins for commercial fishermen. This exception covered fisheries actually closed to fishing by the spill, including claims that the market value of their later salmon catch was decreased on the Japanese market because of concerns about contamination.91 Beyond the direct economic effects of the spill, Alaska natives also sought compensation for the disturbance caused to their way of life. The Ninth Circuit Court of Appeals held that these damages were not compensable because the plaintiffs failed to show "special injury." 92

88 Id. at 808; see also Adkins v. Trans-Alaska Pipeline Liab. Fund, 101 F.3d 86 (9th Cir.1996) (applying the Benefiel test to lost profit claims by electrical utility, cafe, tourist businesses, and boat repair companies).

89 For an overview of the litigation, see Deborah S. Bardwick, Note, The American Tort System's Response to Environmental Disaster: The Exxon Valdez Oil Spill as a Case Study, 19 STAN. ENVTL. L.J. 259 (2000). The author, Bardwick, concludes that despite its magnitude, the recovery for the plaintiffs was inadequate:

Based on the vast extent of litigation and multi-billion-dollar judgments awarded against Exxon, a casual observer might acquire an impression that the legal system fully compensated the losses suffered by those impacted by the spill. However, the legal system in fact denied redress to many plaintiffs who lost most of their livelihoods as a result of damage to natural resources. Many plaintiffs also did not receive compensation for non-market-based, intangible values that the resources had given them.

Id. at 262 (footnote omitted). She calls for "statutes that are specifically written to address the legitimate claims of individuals who suffer significant economic loss as an indirect consequence of the disaster, and create a right for native groups to recover for the actual full extent of their harm from loss of a subsistence lifestyle." Id. at 289.

90 275 U.S. 303 (1927).

91 For a more in depth discussion of the Robins rule, see Victor P. Goldberg, Recovery for Economic Loss Following the Exxon Valdez Spill, 23 J. LEG. STUD. 1 (1994).

92 In re Exxon Valdez: Alaska Native Class v. Exxon Corp., 104 F.3d 1196, 1198 (9th Cir. 1997). The court reasoned:

Admittedly, the oil spill affected the communal life of Alaska Natives, but whatever injury they suffered (other than the harvest loss), though potentially different in degree than that suffered by other Alaskans, was not different in kind. We agree with the district court 
Section $1006(d)(1)$ of the 1990 Oil Pollution Act ${ }^{93}$ provides that the measure of natural resource damages is:

(A) the cost of restoring, rehabilitating, replacing, or acquiring the equivalent of, the damaged natural resources;

(B) the diminution in value of those natural resources pending restoration; plus

(C) the reasonable cost of assessing those damages.94

These costs are to be assessed with respect to restoration plans, which are to be promulgated by federal or state trustees. Double recoveries are precluded by subsection (d)(3). Section 1006(e) requires the President to issue damage assessment regulations. Pursuant to those regulations, a rebuttable presumption of correctness will apply to damage determinations.

One of the components of damages under section 1006 is the cost of restoration. Arguably, only restoration can fully compensate the public for loss of a natural area.95 Unfortunately, one of the lessons of the Exxon Valdez oil spill is that our capabilities in the area of restoration are still quite primitive, and may sometimes be counterproductive. ${ }^{96}$

Paralleling the CERCLA regulations for natural resource damages, the National Oceanic and Atmospheric Administration ("NOAA") developed equivalent rules under the Oil Pollution Act of 1990.97

that the right to lead subsistence lifestyles is not limited to Alaska

Natives. While the oil spill may have affected Alaska Natives more severely than other members of the public, "the right to obtain and share wild food, enjoy uncontaminated nature, and cultivate traditional, cultural, spiritual, and psychological benefits in pristine natural surroundings" is shared by all Alaskans. The Class [of Alaskan Natives] therefore has failed to prove any "special injury" to support a public nuisance action.

Id. (internal citations omitted).

93 Oil Pollution Act (OPA), Pub. L. No. 101-380, Title I, §1006, 104 Stat. 494 (Aug. 18, 1990).

9433 U.S.C. § 2706(d)(1) (2007).

95 See Heidi Wendel, Note, Restoration As The Economically Efficient Remedy for Damage to Publicly Owned Natural Resources, 91 COLUM. L. REV. 430 (1991).

96 See Marguerite Holloway \& John Horgan, Trends in Environmental Technologies: Soiled Shores, SCI. AM., Oct. 1991, at 100.

9740 C.F.R. pt. 112 Appendix F (2008). These rules were upheld in Gen. Elec. Co. v. U.S. Dept. of Commerce, 128 F.3d 767 (D.C. Cir. 1997). The court found the Ohio ruling decisive regarding the general legitimacy of contingent valuation. Id. Any claims that a particular contingent valuation was performed without adequate safeguards could be addressed in a later enforcement proceeding. Id. at 773-74. 
One lesson here is that damages to natural resources are not impossible to fix even when the resources have values that are not captured by markets. Oil spills are a frequent cause of such damage, but floods can also injure public resources like parks or wetlands, and such damage is likely to result from climate change. The problem of identifying the responsible parties may be daunting in the climate case, but at least the means of measuring the harm to nature are well established.

\section{Asbestos}

And then there is the problem of asbestos. In principle, asbestos is just another form of environmental contamination, but the special significance of asbestos litigation warrants separate treatment. The scale of asbestos litigation has been extraordinary, and it is surprising that the asbestos issue has not received more sustained attention from legal academics. As of 2002, according to a RAND report, approximately 730,000 people had filed claims, and at least 8,400 entities had been named as defendants, though most defendants were in eight key industries. ${ }^{98}$ One prominent epidemiological model estimated over 200,000 asbestos-related cancer deaths from 1985 to 2009.99 This is a horrendous death rate: think of three $9 / 11$ incidents per year for over twenty years. Of course, the deaths lacked the drama of even a single $9 / 11$, perhaps accounting for the lack of public attention to the issue. If the asbestos cases had been combined into one lawsuit, the scale of the catastrophe would have indeed been more apparent, but the large number of cases and their special and temporal diffuseness prevented full attention to the scale of the asbestos disaster.

The resulting litigation has had a huge economic impact. Total spending on the litigation through 2002 was about seventy billion dollars. About one third of the spending was in the form of defense costs, another quarter went to plaintiffs' costs and fees, and the remaining forty percent went to compensate plaintiffs. 100 As of mid2004, at least seventy-three defendants had filed for bankruptcy. ${ }^{101}$ In a recent development, W.R. Grace sought the approval of a bankruptcy court to settle all asbestos claims against it for three billion dollars, with

\footnotetext{
98 StEPHEN J. CARROll et Al., ASBestos LiTiGation xxiv-xxv (2005).

99 Id. at $x i x-x x$. The RAND researchers found some empirical confirmation for the model. Id. at 18-19.

$100 \quad I d$. at $\times x v i$.

101 Id. at xxvii.
} 
deferred payments being guaranteed by fifty percent of the company's common stock. 102

The legal system has seemingly been unable to find an appropriate procedural mechanism for handling this flood of litigation. Efforts to consolidate the litigation have been frustrating. In Amchem Products, Inc. $v$. Windsor, ${ }^{103}$ the Court rejected an ambitious effort to use the class action mechanism to settle the claims. The Court held that certification of the settlement class was improper because the interests of some class members were inadequately represented. The question of how to handle claims that have not yet matured has also plagued state courts. In a number of courts, unimpaired plaintiffs are allowed to file claims that are then relegated to the deferred docket; cases can come off the deferred docket only if the claimant meets specified medical criteria such as a diagnosis of malignancy. ${ }^{104}$

There have been a number of other attempts at procedural innovation. Some judges have engaged in large-scale, non-class action consolidations, with fourteen of these consolidated cases involving hundreds (and sometimes thousands) of claimants. ${ }^{105}$ For instance, a Baltimore state judge heard more than eight thousand claims against more than a hundred defendants. ${ }^{106}$ The largest known consolidated trial, involving 9,600 plaintiffs, was held in a specially constructed courtroom at the Jackson County Mississippi state fair grounds. ${ }^{107}$ Consolidation of this number of claims can involve great confusion; for example, one appellate court noted that it was uncertain just how many claims had been decided at trial. ${ }^{108}$

In another effort at consolidation, federal courts have attempted to use the bankruptcy reorganization process as a way of settling massive numbers of claims, in a substitute for the class action procedures rejected in Amchem. Efforts to use prepackaged reorganization plans ("prepacks") have run into some of the same difficulties that plagued the class action mechanism. ${ }^{109}$ The situation cried out for congressional attention, but no legislative solution was forthcoming.

\footnotetext{
102 W.R. Grace to Pay Estimated \$3 Billion to Settle Present, Future Asbestos Claims, 39 ENV. REP. (BNA) 707 (April 22, 2008).

103521 U.S. 591 (1997).

104 CARROLL, supra note 98 , at xxi.

105 Id. at xxii-xxiii.

106 Id. at 33.

107 Id.; see id. at 38-41 (listing large-scale trial consolidations).

$108 \quad$ Id. at 43.

109 See In re Combustion Engineers, 391 F.3d 190 (3d Cir. 2004) (rejecting pre-pack plan as inequitable and lacking statutory authorization).
} 
The asbestos litigation is a cautionary tale about the difficulties confronted by the legal system in handling a massive number of claims. Some leadership from the Supreme Court, either through more aggressive interpretation of current law or through its rulemaking powers, might have led to a more effective procedural mechanism for handling the asbestos cases. With legislative assistance, however, some of these barriers may be surmountable. An American Bar Association report recommends the following procedural reforms for post-disaster litigation:

To improve judicial effectiveness in such cases courts should be granted authority: (a) to concentrate decisionmaking power in a single or small group of judges consistent with the right to jury trial; (b) to locate the proceedings in a single court or limited number of courts; (c) to designate a single set of legal principles to govern consistent with due process and applicable law; (d) to requisition adequate resources and personnel; (e) to utilize reasonable latitude in fact-finding consistent with the right to jury trial; ( $f$ ) to take such steps as will streamline and speed the adjudicatory process; and (g) to recognize the propriety of pro rata and other forms of partial awards where necessary. Authorization to undertake such steps should be the subject of enabling legislation. ${ }^{110}$

Any detailed discussion of procedural reform for mass harms is beyond the scope of this Article. This is a subject of active interest by procedural experts, with significant recommendations for change from the American Law Institute.111 For our purposes, it suffices to say that the asbestos litigation should be regarded as setting a floor-a level of

110 American Bar Association, Rule of Law in Times of Major Disaster (Sept. 2007), Principle 6 (commentary), available at http://www.abanet.org/litigation/ruleoflaw/rol_ disaster.pdf. The text of Principle 6 provides: "To the fullest extent permitted by law the persons affected by a major disaster should be compensated for their losses through insurance coverage and the operation of the judicial system." Id. Principle 7 provides:

Government payment of compensation or additional assistance to persons affected by a major disaster should be considered when government is either implicated in the major disaster or public authorities determine that it is in the public interest to do so. Principles of equal treatment, due process and transparency should Id. govern the distribution of compensation and disaster assistance.

111 ALI, Principles of the Law of Aggregate Litigation (Discussion Draft No. 2). 
process that we already know how to deliver - rather than as a ceiling on what the litigation system can accomplish.

\section{Terrorism}

Completing our survey of the worst hazards of modern life, we turn to terrorism. Prevention has been the primary focus of attention, but compensation issues have not been ignored. In the aftermath of the September 11, 2001 terrorist attack, Congress established a special victim's compensation fund.112 Compensation was limited to individuals who were present at the crash site and who suffered physical injury or death. ${ }^{113}$ The statute covers medical expenses, loss of earnings, "loss of business or employment opportunities[] to the extent recovery for such loss is allowed under applicable State law," and non-economic loss such as physical and emotional pain.114 Victims also had the alternative of going through the tort system, but tort recoveries were limited to the insurance coverage of the defendants, spurred by fears that allowing otherwise might cause litigation to cripple the airline industry. ${ }^{115}$

A special master was appointed to administer the fund. The special master issued a regulation to govern claims that in some instances seemed to go significantly beyond the statutory language. ${ }^{116}$ Although the statute called for an offset for life insurance and pension benefits, the special master reduced the offset to the extent of the individuals' policy payments or pension contributions. The special master also set a floor of approximately $\$ 300,000$ on economic recoveries. He established a guideline for economic loss, based on age, family size, and recent earnings, with a cap for the highest-level incomes. The special master also created a schedule for non-economic losses, with $\$ 250,000$ to each victim, and $\$ 100,000$ each to close relatives. Apparently, the special master's strategy was to "closely enough approximate the range of tort compensation to make no-fault benefits under the Fund an offer that could not be refused by most eligible parties." 117 As it turned out,

\footnotetext{
112 Air Transportation Safety and System Stabilization Act, Pub. L. No. 107-42, 115 Stat. 230 (2001) (codified as 49 U.S.C. $\$ 40101$ (2000 \& Supp. 2005)). For an overview of the scheme, see Rabin \& Bratis, supra note 10. For criticism of the $9 / 11$ compensation scheme, see Elizabeth Berkowitz, The Problematic Role of the Special Master: Undermining the Legitimacy of the September 11th Victim Compensation Fund, 24 YALE L. \& POL'Y REV. 1 (2006). The opt-out cases are now being considered in federal district court, along with claims for respiratory damages.

$113 \quad 49$ U.S.C. $\$ 40101$.

$114 \quad I d . \S 402(5),(7)$.

115 Id. $\$ \S 408,201(\mathrm{~b})$.

116 See 67 Fed. Reg. 11233 (Mar. 13, 2002) (to be codified at 28 C.F.R. $\$ 104$ (2008)).

117 Rabin and Bratis, supra note 10, at 341.
} 
ninety-seven percent of the surviving families applied to the fund, with only seventy families opting out. ${ }^{118}$

It would be a mistake to think that the harms of terrorism can be redressed only through such a legislative compensation mechanism. Common law liability has also been a real factor. Two recent cases indicate the potential for liability.

Stanford v. Kuwait Airways Corp. ${ }^{119}$ involved the hijacking of a Kuwait airlines flight. Four terrorists boarded a Middle Eastern Airlines ("MEA") flight in Beirut. The flight ended in Dubai, where the four terrorists connected with a Kuwait Airways flight bound for Karachi, Pakistan. Three American diplomats were also on board the second flight. Shortly after take-off from Dubai, the terrorists hijacked the plane, which landed in Tehran. The plane sat on the airport tarmac for days while the terrorists tortured the three American diplomats, finally murdering two of them. ${ }^{120}$ The surviving diplomat and the estates of his two deceased colleagues brought suit against MEA. They claimed that MEA's negligence was a proximate cause of the injuries and deaths occurring aboard the Kuwait Airways flight. The court held that a jury could have reasonably found that when Kuwait Airways boarded

118 The Price-Anderson Act, 42 U.S.C. $\$ 2210$ (2000), is another example of a compensation scheme designed to limit tort litigation in order to protect a critical industry. The Act caps the total liability of the nuclear industry for damages resulting from a single nuclear accident, in return modifying normal tort rules to make it easier to establish liability. The purpose of the statute was to enable the nuclear industry to obtain insurance coverage. The Act also provides for assessments of the industry as a whole to cover additional victim compensation. The Supreme Court upheld the Act against a takings claim in Duke Power Co. v. Carolina Env. Study Group, Inc., 438 U.S. 59 (1978). For further discussion of the statute, see Dan M. Berkovitz, Price-Anderson Act: Model Compensation Legislation? - The Sixty-Three Million Dollar Question, 13 HARV. ENVTL. L. REV. 1 (1989).

A more recent scheme was enacted to protect pharmaceutical companies from claims relating to possible bioterror attacks. At the end of 2005, the President signed the Public Readiness and Emergency Preparedness Act ("PREPA"). 42 U.S.C. \$ 247d-6d-e (2006). The statute provides immunity (for anything less than willful misconduct) for pharmaceutical manufacturers for producing vaccines and other countermeasures for a biological emergency such as a bio-terror attack or pandemic flu outbreak. The Secretary of HHS seems to have broad discretion in declaring such an emergency. Once an emergency is declared, a "Covered Countermeasure Process Fund" is established. No appropriations will be provided until after the emergency is declared and the fund is established. Thus, there is no guarantee that funding will be forthcoming, which could leave victims in the position of having their tort remedies preempted but without any alternative means of compensation. See Brian Kurt Copper II, Higher and Dry? The Public Readiness and Emergency Preparedness Act and Liability Protection for Pharmaceutical Manufacturers (April 11, 2006), available at http://papers.ssrn.com/sol3/papers.cfm?abstract_id=896299. For a discussion of these statutory compensation schemes, see Robert Rabin, The Renaissance of Accident Law Plans Revisited, 64 MD. L. REV. 698 (1995).

$119 \quad 89$ F.3d 117 (2nd Cir. 1996).

$120 \quad$ Id. at 119. 
connecting passengers in Beirut, it knew or should have known that some might be terrorists. ${ }^{121}$

The first major issue in Stanford was the existence of a duty owed by Kuwait Airlines to the plaintiffs. The court held that MEA had a duty to protect passengers on connecting flights from unreasonable risks. The court found it irrelevant that the victims were not passengers on an MEA flight because of the nature of the risk. ${ }^{122}$

A related issue was the foreseeability of the specific injury that occurred. In this case, there was evidence that MEA knew of the threatened attacks by Hezbollah terrorists and that terrorists were boarding flights in dirty airports to infiltrate other airlines. ${ }^{123}$ Moreover, even a child would have been suspicious of the unusual behavior of the four hijackers who boarded in Beirut. A reasonable person could surely foresee a risk of hijacking from passengers who purchased last-minute tickets with cash, checked no luggage for a flight from the Middle East to the Far East, and took a bizarrely circuitous route. ${ }^{124}$ A jury could reasonably find that the zone of risk stretched at least as far as the innocent passengers aboard flights with which the four hijackers would eventually connect. ${ }^{125}$

The second case, In re September 11 Litigation, 126 involved opt-outs from the compensation fund. The defendants included the airlines, airport security companies, and airport operators. All were accused of negligently failing their security responsibilities. ${ }^{127}$ In addition, the plaintiffs accused the owners and operators of the World Trade Center of negligently designing, constructing, maintaining, and operating the buildings, as well as botching the evacuation. ${ }^{128}$ Airline passengers also sued the plane manufacturers for manufacturing inadequate cockpit

\footnotetext{
121 Id. at 124.

122 Id. at 124-25. Indeed, the evidence suggested that the risk was fairly obvious. The plaintiffs demonstrated that MEA was aware of the weak security at the Beirut airport. For instance, the Lebanese military had, but did not use, metal detectors, and X-ray equipment was unavailable. Id. at 120 . In the court's view, a jury could reasonably find that MEA knew or should have known of the danger that terrorists would try to board their airline only to transfer later to a vulnerable, interline target airplane. This was particularly true because of heightened political tensions and an ongoing terrorist campaign that posed continuing threats against Americans and Kuwaitis. Id. at 124.

$123 \quad 89$ F.3d at 125.

124 Id.

125 Id.

126280 F. Supp. $2 d 279$ (S.D.N.Y. 2003).

127 Id. at 288.

128 Id. at $288,298$.
} 
doors, which allowed the hijackers to invade the cockpits and take over the aircraft. 129

The court held that the airlines and security companies owed a duty of care to victims on the ground to screen passengers and their belongings, and that the plane crash was within the class of foreseeable hazards outcomes. Similarly, the WTC's owners and managers had a duty to implement adequate fire safety measures, even in the case of a fire caused by hijackers. ${ }^{130}$ Likewise, the court found that the terrorists unauthorized entry into the cockpit was not unforeseeable and did not constitute an "intervening" or "superseding" cause that could, as a matter of law, break the chain of causation proceeding from defective design of the cockpit doors. ${ }^{131}$

Duty was once again a key issue. The court balanced several factors: the reasonable expectations of parties and society generally, the proliferation of claims, the likelihood of unlimited or insurer-like liability, disproportionate risk and reparation allocation, and public policies affecting the expansion or limitation of new channels of liability. ${ }^{132}$ The court emphasized that in today's world, people depend on others charged with special duties to protect them. ${ }^{133}$ For instance, passenger screening is performed for the benefit of passengers and those on the ground. ${ }^{134}$ More generally, New York courts have found that aircraft owners and operators owe a duty to those on the ground who may be harmed or sustain property damage resulting from improper or negligent operation of an aircraft. ${ }^{135}$

The court then turned to an inquiry regarding "disproportionate risk and reparation allocation." 136 Airlines, airports, and security firms could best control the boarding of airplanes and guard against hijackings and

129 Id. at 287-88. Because Virginia does not recognize strict liability for product defects, the counts against the airplane manufacturers were dismissed as to the victims of the Pentagon crash. Id. at 306.

130 Id. at 300.

131280 F. Supp. 2d at 308-10.

132 Id. at $290-92$.

133 Admittedly, the court said, New York courts have been cautious about imposing liability for failure to control the conduct of others because of practical concerns about potentially limitless liability and about unfairness. But courts have imposed a duty based on the defendant's control over the third party tortfeasor's actions, or a relationship with the plaintiff requiring the defendant to protect the plaintiff from the conduct of others. Id. at 290-91.

134 Id. at 294-95. The court relied in part on the Stanford case for the proposition that airlines have a duty not only to passengers on the flights they operate but also to passengers on connecting flights, and thus may be liable when they allow terrorists to board planes. Id. at 295.

135 Id. at 294-96.

136 Id. at 293 (quotation marks omitted). 
the dangers they present to crew, passengers, and those on the ground. The court explained,

The scope of duty to a particular class of plaintiffs depends on the relationship to such plaintiffs, whether plaintiffs were within a zone of foreseeable harm, and whether the harm was within the class of reasonably foreseeable hazards that the duty exists to prevent. ...

In order to be considered foreseeable, the precise manner in which the harm was inflicted need not be perfectly predicted. ${ }^{137}$

Plaintiffs also have the ability to pursue claims against terrorist organizations and their supporters. For instance, in Gilmore v. Palestinian Interim Self-Government Authority, ${ }^{138}$ the plaintiffs were the family of the victim of a terrorist shooting in Jerusalem. They brought suit against the Palestinian authority as well as some individual defendants who were allegedly responsible for planning and carrying out the shooting. The court dismissed the individual defendants for lack of personal jurisdiction, but allowed the charges against the Palestinian Authority to go forward.

Liability was based on a federal statute that authorizes claims against perpetrators of international terrorism, provided three elements are met. First, the defendant's activities must involve violent acts that would violate U.S. criminal law if performed in America. Second, the acts must "appear to be intended" to intimidate or coerce a civilian population, to influence government policy, or to change a government's conduct through mass destruction. ${ }^{139}$ There is an exception for "acts of war," but despite the common term "war on terror," this exception has

137 Id. at 295. Turning to the owners and operators of the World Trade Center, the court also concluded that a duty of care existed. The plaintiffs and society could expect them to follow applicable safety and fire codes and to create appropriate evacuation routes and procedures. They were best able to guard against the risks of fire, and their liability exposure was limited by statute to their insurance coverage. Id. at 293-94. The court also held that plaintiffs had sufficiently pleaded alleged proximate cause given the defendants' knowledge of the possibility of terrorist acts, large-scale fires, and even airplane crashes at the World Trade Center. Id. at 296. On the other hand, the court pointed to the possibility that the acts of the terrorists might be considered an intervening cause, depending on the evidence at trial. Id. at 292 n.7 \& 293.

138422 F. Supp. 2 d 96 (D.D.C. 2006).

139 Anti-Terrorism Act of 1990, Pub. Law. No. 101-519, 104 Stat. 2250 (Nov. 5, 1990), amended by Pub. Law. No. 107-56, Title VIII, § 802(a), 115 Stat. 376 (Oct. 26, 2001) (codified at 18 U.S.C. \$ 2331 (2006)). 
been held inapplicable to al Qaeda because it is not a national military force. ${ }^{140}$ The statute provides for treble damages, and courts have upheld damage awards in the \$100-200 million range (which may or may not ever be collectable, of course). ${ }^{141}$

Statutory liability also extends to those who aid and abet terrorist actions. In Boim v. Quranic Literacy Institute and Holy Land Foundation for Relief and Development, ${ }^{142}$ the parents of an American killed in Israel by Hamas sued Islamic charities that allegedly helped fund Hamas. The Seventh Circuit held that merely funding Hamas was not enough to establish liability. Even small donations made knowingly and intentionally in support of terrorism are enough for liability. As the court explained,

[T] here would not be a trigger to pull or a bomb to blow up without the resources to acquire such tools of terrorism and to bankroll the persons who actually commit the violence. Moreover, the organizations, businesses and nations that support and encourage terrorist acts are likely to have reachable assets that they wish to protect. The only way to imperil the flow of money and discourage the financing of terrorist acts is to impose liability on those who knowingly and intentionally supply the funds to the persons who commit the violent acts. ${ }^{143}$

Given the prevalence of terrorism in today's world, we have not seen the last of claims against those who have failed to provide adequate protection, as well as those who may have provided material assistance to terrorists. The preliminary indications are that courts are open to finding liability where the potential for terrorist acts is sufficiently foreseeable.

\section{THE POTENTIAL CONTRIBUTION OF TORT LAW}

As we have seen, damages for defective flood control are readily available under California law against the state government, but far

\footnotetext{
140 Morris v. Khadr, 415 F. Supp. 2d 1323, 1333-34 (D. Utah 2006). See also Estate of Klieman v. Palestinian Authority, 424 F. Supp. 2d 153, 164 (D.D.C. 2006) (exception does not apply if defendant's actions violated the laws of war).

141 See Ungar v. Palestine Liberation Org., 402 F.3d 274, 282 (1st Cir. 2005) (\$116 million); Knox v. Palestine Liberation Org., 442 F. Supp. 2d 62, 77-80 (S.D.N.Y. 2006) (\$192 million in damages); Morris v. Khadr, 415 F. Supp. 2d 1323, 1337-38 (D. Utah 2006) (\$102 million).

142291 F.3d 1000 (7th Cir. 2002).

143 Id. at 1021.
} 
more difficult if not impossible under federal law when the defendant is the Army Corps of Engineers. Environmental claims have amounted to billions of dollars, whether from oil spills, asbestos, lead, or other dangerous substances. Claims based on terrorist acts are beginning to find a receptive judicial audience. In short, the judicial system has responded in a variety of ways to claims for catastrophic losses.

In considering the desirability of compensation for catastrophic risks, we need to think broadly about the societal interests at stake. The tort system - and by extension, other compensation schemes - has several goals. ${ }^{144}$ Probably the two most important are deterring harmful conduct (the efficiency or deterrence rationale) and corrective justice (restoring moral balance by rectifying harm). Loss distribution (which can be considered a way of providing insurance against social risks) is another goal, perhaps more important in social compensation schemes than in tort. Finally, there are goals oriented to maintaining social cohesion providing redress for social grievances or exhibiting social solidarity with victims. ${ }^{145}$

The present discussion will be limited to fault-based liability. The concerns about imposing liability for large-scale public risks are formidable enough in any event. If courts are willing to surmount those barriers, it seems likely that they will usually require some kind of showing of fault rather than imposing strict liability. In addition, liability for catastrophic risks poses a significant likelihood of insolvency, a situation in which economic analysts say strict liability can lead to under-deterrence. ${ }^{146}$ Thus, for present purposes, we can assume that the conduct is of a kind that society would like to deter - or at least, activity, the volume of which society would like to decrease - and that at least some actor's conduct was responsible for the harm in question. Moreover, catastrophic losses are precisely the kinds of risk for which loss-spreading, through some kind of insurance scheme, seems most warranted. Yet, private insurance coverage for victims is problematic.

Thus, the arguments for negligence liability or some similar faultbased theory may seem clear. But, as we shall see, some significant difficulties remain to be confronted.

\footnotetext{
144 For discussion of these goals, see KENNETH S. ABRAHAM, THE FORMS AND FUNCTIONS OF TORT LAW 14-20 (2d ed. 2002). For a more general discussion of how these goals have shaped the role of government, see DAVID A. MOSS, WHEN ALL ELSE FAIL: GOVERNMENT AS THE ULTIMATE RISK MANAGER 253-91 (2002).

145 For an insightful discussion of this solidarity rationale in the context of catastrophic natural events, see Stephen D. Sugarman, Roles of Government in Compensating Disaster Victims, in ISSUES IN LEGAL SCHOLARSHIP, available at www.bepress.com/ils.

146 See Michael G. Faure, Financial Compensation for Victims of Catastrophes: A Law and Economics Perspective, 29 LAW AND POL'Y 339, 342-43 (2007).
} 


\section{A. Deterrence}

A core function of tort law is to deter undesirable conduct. ${ }^{147}$ Defendants in catastrophic risk cases are generally organizations, given the unlikelihood that an individual defendant will have the assets to provide more than a trivial amount of compensation. ${ }^{148}$ Presumably, business enterprises are likely to take a more rational approach to potential liability than ordinary individuals. The ordinary assumption of tort law is that businesses respond to such liability incentives.

Governmental organizations are not profit-maximizing institutions, but still large tort awards require fiscal dislocations that are not likely to be politically popular. Thus, government organizations also have an incentive to avoid conduct that can lead to liability, although this motive probably must compete with other political incentives.

The deterrent function of tort law is reinforced by the organizational dynamics regarding catastrophic risks. An individual's mistake may be the immediate cause of a catastrophic failure, but there is often a deeper organizational flaw that makes that mistake possible and prevents it from being corrected. ${ }^{149}$ Avoiding catastrophic risks can be a challenging task for organizations. Many organizations engage in activities that can cause massive harm if things go wrong-just consider electrical utilities that operate nuclear power plants, government agencies that build flood control systems, and operators of blood banks. To prevent devastating accidents or to take adequate precautions against other causes of disaster, organizations must be alert for minor unexpected events that may be harbingers of larger risks; they must react decisively when mistakes occur to reform the systems which made the mistakes possible. They also need to track comparable issues at other organizations to learn from their mistakes and their precautions.

None of this comes very naturally to organizations, which often find it easier to perfect existing routines, optimizing their behavior under "normal" conditions but creating little capacity to detect or respond to the abnormal. This stagnation is especially dangerous for organizations

\footnotetext{
147 Abraham, supra note 72 , at 16 . For some misgivings about the efficacy of tort liability as a deterrent, see Gary T. Schwartz, Reality in the Economic Analysis of Tort Law: Does Tort Law Really Deter?, 42 UCLA L. REV. 377 (1994).

148 Of course, it is conceivable that an individual defendant might have extraordinary personal wealth, although so far this has not yet been the case in any of the reported cases involving catastrophic loss.

149 Consider, for example, the organizational flaws that lead up to $9 / 11$. See The $9 / 11$ Commission, The 9/11 Commission Report: Final Report of the National Commission on Terrorist Attacks Upon the United States 339-60 (2004).
} 
that deal with major emergencies such as floods, fires, and other natural and manmade disasters.

Organizations that await major failures before adapting tend to enter crisis mode and find learning and response even more difficult. 150 For example, following the demise of the space shuttle Challenger, NASA faced political pressures, inertia, and resource constraints that expedited some organizational changes but made other structural and cultural adjustments more difficult. ${ }^{51}$ Furthermore, in the absence of a significant environmental change or destabilizing event, social science research indicates that lessons learned in organizations often tend to be forgotten or misapplied. ${ }^{152}$

Even worse, because of the infrequency of major disasters, trial and error learning may lead organizational members to forget lessons from past disasters. Social scientists contend that in the case of disaster preparedness, trial and error processes lead to "superstitious learning[]" - organizational leaders concluding that resources designated for disaster preparedness are idle and should be applied elsewhere. ${ }^{153}$ Disaster preparation calls for a different form of learning in which organizations draw on not only their own experiences, but also those of other organizations. Such network learning exists for a variety of learning processes. 154

Tort liability may promote this process of institutional learning in two ways. First, it multiplies the number of times the lesson of any particular catastrophic event is repeated. Individuals learn about the causes of a catastrophic failure when it happens, again when the lawsuit is filed, and yet again when the judgment is entered. The later stages, like booster shots for a vaccine, reinforce the initial knowledge of an organizational disaster. Second, tort liability enlists new organization members in disaster prevention. There is some evidence that involving

150 K.H. Roberts, P. Madsen, \& V. Desai, The Space Between in Space Transportation: A Relational Analysis of the Failure of STS 107, in ORGANIZATION AT THE LIMT: LESSONS FROM THE COLUMBIA DISASTER 81-98 (M. Farjoun \& W. Starbuck eds., 2005).

151 HOWARD E. MCCURDY, INSIDE NASA: HIGH TECHNOLOGY AND ORGANIZATIONAL CHANGE IN THE U.S. SPACE PROGRAM (1993).

152 Pabli Martin De Holan \& Nelson Phillips, Remembrance of Things Past? The Dynamics of Organizational Forgetting, 50 MGMT. SCI. 1603 (2004); James G. March, et al., Learning from Samples of One or Fewer, 2.1 ORG. SCI. 1 (1991).

153 Barbara Levitt \& James G. March, Organizational Learning, 14 ANN. REV. SOC. 319, 335 (1988).

154 See, e.g., Christine M. Beckman \& Pamela R. Haunschild, Network Learning: The Effects of Partners' Heterogenity of Experience on Corporate Acquisitions, 47 ADMIN. SCI. Q. 92 (2002); Joel A.C. Baum \& Paul Ingram, Survival-Enhancing Learning in the Manhattan Hotel Industry, 1898-1980, 44 MGMT. SCl., 996 (1998); Linda Argote et al., The Persistence and Transfer of Learning in Industrial Settings, 36 MGMT SCI. 140 (1990). 
multiple organizational units can facilitate organizational learning. ${ }^{155}$ Because of the potential scale of liability, shareholders and others with financial interests - including management officers with stock optionshave an interest in ensuring that the company does not implode due to disaster liability. No politician wants to be responsible for bankrupting the government. Moreover, the legal department in the organization also acquires an interest in ensuring that steps are taken to avoid liability. Thus, a broader set of organizational viewpoints are brought to bear on disaster prevention activities.

Recent events in California illustrate how liability can focus organizational attention. The threat of liability helped spur the Governor's proposal for a "massive" levee improvement program in the Central Valley, which faces dire flood risks. ${ }^{156}$ A Central Valley newspaper summed up the situation:

For the last four years, California leaders have lived with the reality that state taxpayers could become liable for billions of dollars in damages the next time a stateowned levee fails in the Central Valley.

Such levees protect more than 200,000 homes and $\$ 47$ billion in property, according to state figures. Potentially, a single flood could bankrupt the state.

In recent years, Gov. Arnold Schwarzenegger and state lawmakers have poured millions of dollars into levee repairs and have helped pass two bond issues that will deliver another $\$ 4.9$ billion. Those expenditures will help reduce the flood risk, but by themselves, they won't fully shield the state from legal exposures caused by recent court decisions. ${ }^{157}$

155 See Christina Fang, Jeho Lee, \& Melissa A. Schilling, Exploration and Exploitation: The Influence of Organizational Structure on Organizational Learning (March 2007), available at http://mackcenter.wharton.upenn.edu/TMiniPapers07/Fang\%20Lee\%20Schilling_Explor at\&Exploit.pdf.

156 Editorial, Give Local Governments a Share of California's Levee Liability, OAKLAND (CAL.) TRIB., April 6, 2006. Confirming awareness of the Paterno decision by political leaders, a state legislator is quoting as saying, "I think it is going to have long-lasting and rather severe financial effects on the state of California." Id. Hurricane Katrina undoubtedly also had an effect in bringing flood issues to the attention of California lawmakers.

157 Editorial, Flood Flip-Flops: Where does Governor Stand? State is on the Hook for Massive Damages; Local Governments Need to Share in Risk, SAN DIEGO COUNTY WATER AUTHORITY, March 11, 2007. The editorial notes that the Schwarzenegger administration initially called 
This episode confirms the more general arguments that prospective liability for catastrophic risks can have a salutary effect on organizational priorities.

That individuals respond to incentives is an article of faith among economists, who also tend to view businesses, if not governments, as rational actors. In any event, it is hard to believe that potential liability increases the amount of risky behavior by large organizations. Presumably, organizations do not get to be large without being able to respond, at least crudely, to the incentives presented by their environments. Thus, at least as a working assumption, we can proceed on the basis that tort liability has at least some beneficial incentive effect even on large organizations.

\section{B. Corrective Justice}

Scholars vigorously debate whether corrective justice - the idea of "just deserts" - has an independent role in tort law, as well as how to define that role. ${ }^{158}$ In any event, many people do share the intuition that wrongdoers have a moral duty to compensate their victims. Application of this intuition to catastrophic risks can involve difficulties, not because of the absence of wrongdoing, but because the defendants are typically entire organizations rather than the individuals directly involved in causing the harm.

Admittedly, the case for compensation as a form of "just deserts" is strongest when compensation is provided by the particular individuals who are responsible for harm, or when responsible individuals have benefited from conduct that imposes risk on others. With large-scale risks, this may be difficult because of the way responsibility is diffused through organizations. Furthermore, the specific individuals who were at fault for a catastrophic loss often lack the resources to cover more than a small (and perhaps even trivial) portion of the damages. The question, then, is whether it is appropriate to impose liability on the organization and indirectly on stakeholders or taxpayers, even though they were not immediately involved in the harmful conduct and may not even have

for new tort statutes and a state constitutional amendment to modify Paterno, but later retreated from that stance. $I d$.

158 For some classic early contributions to the debate, see Richard A. Posner, The Concept of Corrective Justice in Recent Theories of Tort Law, $10 \mathrm{~J}$. LEGAL STUD. 187 (1981); George P. Fletcher, Faimess and Utility in Tort Law, 85 HARV. L. REv. 537 (1972). For an effort at synthesis, see Gary T. Schwartz, Mixed Theories of Tort Law: Affirming Both Deterrence and Corrective Justice, 75 TEx. L. REv. 1801 (1997). A good summary of ideas about corrective justice can be found in Christopher H. Schroeder, Corrective Justice and Liability for Increasing Risks, 37 UCLA L. REV. 439, 443-51 (1990). 
been aware of the risk. There is a vigorous debate on this issue, particularly in the context of corporate criminal liability.

In some cases, tort liability can be justified on the basis of unjust enrichment. If shareholders have benefited because the company has cut corners on safety, they clearly should make recompense. The same is true for those who enjoyed lower taxes because their government failed to take necessary precautions. But such unjust enrichment may be difficult to show, particularly when there is a significant lag between the wrongful activity and the materialization of the risk. For instance, the original shareholders who benefited from the lower costs of shoddy construction may already have sold out at a handsome profit to new shareholders who had no knowledge of the risk.159

Some moral theories go beyond this kind of individualistic approach and hold groups liable regardless of the individual situations of their members. ${ }^{160}$ We might think, for example, that citizens accept moral responsibility for the actions of their governments in return for the right to participate in democratic politics and receive the benefits of government actions, or that government as entities should be considered to have moral rights and responsibilities, or that they suffer from a moral taint from being associated with their government's wrongful acts. Exploring these questions in depth, however, would take us too far afield. Even if such theories do not make an affirmative case for liability, they may at least be strong enough to convince us that shareholders and taxpayers do not face an injustice when they incur financial sacrifices due to liability.

Under many circumstances, "just deserts" may provide a less powerful reason than deterrence for imposing liability for catastrophic risks. Nevertheless, it may sometimes be an important supporting factor, particularly when stakeholders have received benefit from wrongful acts that they had the capacity to control. ${ }^{161}$

\section{Risk Spreading}

Risk spreading can provide a powerful justification for liability for catastrophic risks. Understanding this point requires an understanding

\footnotetext{
159 I discuss this and other aspects of corrective justice in the context of climate change in a forthcoming article, Daniel A. Farber, The Case for Climate Compensation: Justice for Climate Victims in a Complex World, 2008 UTAH L. REV. 377.

160 For discussion of those theories, see Eric A. Posner \& Adrian Vermeule, Reparations for Slavery and Other Historical Injustices, 103 CoLUM. L. REv. 689, 703-11 (2003).

161 For a discussion of this issue in the context of climate change, see Daniel A. Farber, supra note 159.
} 
of the complicated relationship between catastrophic risks, insurance, and government intervention.

Flood damages provide a good starting point. Although the federal government generally has no legal liability, even if floods are caused by its negligence, it has often found itself in the position of bailing out flood victims with various forms of disaster relief. The flood insurance program is intended both to regularize this practice and to provide incentives to municipalities and individuals to limit their risk exposure. The basics of flood insurance have been succinctly summarized by FEMA:

In 1968, Congress created the National Flood Insurance Program (NFIP) in response to the rising cost of taxpayer funded disaster relief for flood victims and the increasing amount of damage caused by floods.

... Nearly 20,000 communities across the United States and its territories participate in the NFIP by adopting and enforcing floodplain management ordinances to reduce future flood damage. In exchange, the NFIP makes federally backed flood insurance available to homeowners, renters, and business owners in these communities. 162

Flood insurance presents a tricky set of problems. ${ }^{163}$ If it is priced too high, people simply may fail to insure. If it is priced too low, society is in effect subsidizing individuals to build in high-risk areas. Obviously, the solution is to price it "just right" - but finding the right level may not be easy, especially since there is no private market to use as a benchmark. Moreover, communities have not always followed through on promises to control development in flood plains-recall from Part I that California has found it necessary to create a liability threat in order to motivate better floodplain planning.

162 FEMA, About Flood Insurance, available at http://www.fema.gov/news/newsrelease. fema?id=18921.

163 For fuller discussion of issues relating to flood insurance, see DANIEL A. FARBER \& JIM CHEN, DISASTERS AND THE LAW: KATRINA AND BEYOND 178-84 (2006); Edward Pasterick, The National Flood Insurance Program, in PAYING THE PRICE: THE STATUS AND ROLE OF INSURANCE AGAINST NATURAL DISASTERS IN THE UNITED STATES (Howard Kunreuther \& Richard J. Roth eds., 1998). 
Private insurance for catastrophic risks also presents distinctive issues. ${ }^{164}$ As Steve Sugarman explains:

... Indeed, it is precisely the dramatically large event that leads to widespread disastrous consequences that is frequently specifically excluded from certain standard private insurance policies. For example, the destruction of one's home or other buildings is generally not covered by ordinary property insurance (or homeowners') policies if the harm is caused by things like war, nuclear radiation, floods, and, at least in some places, earthquakes. ${ }^{165}$

Demand for such insurance may be low because people misjudge the likelihood of low-probability events; they may also prefer to incur larger

164 For more in-depth coverage of issues relating to private insurance, see Dwight $M$. Jaffee \& Thomas Russell, Terrorism Rethinking the Government's Role Insurance, in ISSUES IN LEGAl SCHOLARSHIP, CATASTROPHIC RISKS: PREVENTION, COMPENSATION, AND RECOVERY (2007): Article 5, available at http://www.bepress.com/ils/iss10/art5; Howard Kunreuther, Has the Time Come for Comprehensive Natural Disaster Insurance?, in ON RISK AND DISASTER: LESSONS FROM HURRICANE KATRINA (Ronald J. Daniels, Donald F. Kettl \& Howard Kunreuther eds., 2006); HOWARD KUNREUTHER AND RICHARD J. ROTH, SR., PAYING THE PRICE: THE STATUS AND ROLE Of INSURANCE AGAINST NATURAL DISASTERS IN THE UNITED STATES (1998).

165 Sugarman, supra note 145, at 6 (footnote omitted). Sugarman explains some of the reasons why private insurers may be reluctant to enter this market:

First of all, they find themselves unable to sensibly price the insurance, both because the precipitating event too infrequently occurs and when it does the amount harm it will cause is not really predictable. Moreover, it is especially worrying to insurers that the catastrophe might occur markedly earlier than expected, so that not enough premiums would yet have been accumulated, thereby putting an insurer at risk of insolvency. Even if the timing and scale of the risk were reasonably predictable, however, insuring against infrequent disasters would require a long accumulation and investment of premium income in a way that is not altogether attractive to insurers (and re-insurers who might be enticed to spread the risk beyond the insurer who initially sold coverage to its customers). Among other things, U.S. tax law rules discourage insurance lines that involve premium collection without payouts, even if funds are set aside for eventual losses. Besides, when the gigantic-loss event finally occurs, insurers could be swamped by the claims-handling process, having to rely on out-of-area and/or inexperienced staff who are likely to be more costly and less efficient. As a result, catastrophic risk coverage might simply be an unattractive product for mainstream insurers to offer.

Id. (internal citations omitted). 
uncertain losses than smaller, but more certain, ones. ${ }^{166}$ The insurance industry seems reluctant to provide coverage for large-scale natural disasters. This reluctance may be in part because of the difficulty of assessing risk levels, ${ }^{167}$ as well as the underwriting costs associated with maintaining large levels of reserve or reinsurance, not to mention competition from various government-subsidized schemes. ${ }^{168}$

The federal flood insurance program is based in part on the reluctance of the private market to provide such insurance on a broad scale. To fill similar gaps in insurance coverage, state governments have also sometimes stepped in. For instance, in the aftermath of Hurricane Andrew, Florida established a backup fund for individuals who could not get private coverage, funded by assessments of insurers. (This bears some resemblance to the more familiar "designated risk" pool for car insurance.) The number of policy holders dropped by over ninety percent in just a few years, but the remaining coverage still represented over ten billion dollars in exposure. Florida also offers reinsurance to private insurers at subsidized rates. ${ }^{169}$ These solutions, however, are not entirely satisfactory:

Private losses from catastrophes in the United States have been rising faster than premiums, population, and economic activity, and are correlated with a rising rate of impairments, or conditions where insurers' liabilities exceed their assets. In Florida and Louisiana alone, more than 600,000 homeowners' property policies were cancelled or not renewed in 2005. The U.S. residual markets - state-mandated pools where commercial markets otherwise fail - contain about three million customers today, and the number is rising. If the situation is left unchecked, even more of the burden will shift to consumers and governments and growth of the insurance sector itself could be slowed. ${ }^{170}$

\footnotetext{
166 Faure, supra note 146 , at 346.

167 Id. at 348.

168 For a more extensive discussion of these issues, see Howard C. Kunreuther \& Erwann O. Michel-Kerjan, Climate Change, Insurability of Large-Scale Disasters, and the Emerging Liability Challenge, 155 U. PA. L. REV. 1795, 1821-33 (2007) (stressing the difficulty of quantifying risks as an explanation).

169 For discussion of the Florida programs, see Rabin \& Bratis, supra note 10, at 345-47.

170 Christina Ross, Evan Mills, \& Sean B. Hecht, Limiting Liability in the Greenhouse: Insurance Risk-Management Strategies in the Context of Global Climate Change, 26A STAN. ENVTL. L.J. 251, 257 (2007). See also Martin F. Grace \& Robert W. Klein, Facing Mother
} 
The government has also supported insurance for terrorism risks. For instance, in Britain and Holland, the government provides reinsurance for terrorism risks. ${ }^{171}$ The German government covers losses from three billion euros up to ten billion. ${ }^{172}$ Before 9/11, private insurance for terrorist risks was commonly available, but private insurers then withdrew from the market. (By 2003, property and business interruption insurance claims filed as a result of 9/11 had reached almost $\$ 20$ billion. ${ }^{173}$ ) As a result, the federal government became a reinsurer via the Terrorism Risk Insurance Act of 2002.174 Whether this reinsurance function is desirable is far from clear.

The upshot of all of this is that private insurance markets do not operate well, and may not operate at all, for catastrophic risks. Government interventions have had some success in keeping insurance markets operative with the help of implicit subsidies such as government reinsurance. But we do not know how to create a truly satisfactory, efficient, and equitable mechanism for insuring against catastrophic risks.

In this setting, the risk-spreading function of tort law attains heightened importance. If private firms have tort liability, the burden is put on the shareholders and thereby spread through the securities markets. If government agencies have tort liability, the burden is put on the taxpayers and again shared widely. To the extent that private insurers are in the market, the burden of covering catastrophic risks can be reduced if they are allowed to subrogate to the tort claims of their insureds. In any event, to a much greater extent than is true of more easily insurable risks, such as routine auto accidents or house fires, the tort system's ability to spread risks is a major advantage.

The importance of catastrophe liability as a means of risk spreading also counters the argument that we should avoid placing crushing burdens on organizations. This may be true in other circumstances because there are superior ways of distributing risks. But in the case of catastrophic risks, satisfactory alternatives may not exist, and liability can allow society to tap the unmatched ability of the securities markets to spread risk broadly.

Some may fear that this liability will push businesses into bankruptcy. Although bankruptcy poses risks to stakeholders, such as

Nature, REG. 28, 32 (Fall 2007) ("Writing homeowners insurance in Florida has been a losing proposition that is getting worse, not better.").

17 See Faure, supra note 146, at 357.

172 See id.

173 See Rabin \& Bratis, supra note 10 , at 326.

174 See id. at 325. 
employees, the bankruptcy laws do allow otherwise viable business entities to reorganize and continue operation, protecting employees and other stakeholders. Shareholder value may be wiped out, but shareholders have access to the biggest risk spreading mechanism in human history: modern international financial markets. They can hold diversified stock portfolios or otherwise hedge against risk. (As recent events in the financial markets indicate, this form of risk-spreading is not absolutely foolproof, but it works well except in the case of rare financial meltdowns-and during meltdowns, the added risk from potential corporate tort liability is trivial compared with the losses from market fluctuations.) Thus, transferring risk to shareholders from disaster victims is not something that we should fear. The risk that third-parties such as employees may be harmed by bankruptcy should not be dismissed, but we should not confuse the need to protect such innocent parties with the interests of shareholders who are often in a much better position to diversify risks than the victims of catastrophic risks.

In sum, imposing liability for catastrophic risks can serve the goals of deterring undesirable conduct and can also reinforce society's otherwise limited ability to spread the costs of catastrophe through private or governmental insurance. Because the important defendants will nearly always be organizations, the applicability of corrective justice depends on our willingness to hold stakeholders, such as current shareholders or taxpayers, responsible for the sins of the organization.

\section{NAVIGATING the PITfalls: Judicial COMPETENCE, MANAGEABILITY, AND PROOF}

The asbestos cases are all the warning we could ask of the difficulties that catastrophic risks can pose for the judicial system. Improvements in civil procedure may ameliorate these difficulties, but we should also consider other possible options. One option is to move compensation away from the judiciary to an administrative agency; another is to craft liability rules that reduce manageability issues. Even if an administrative system would be better than processing claims through case-by-case litigation, judicial liability may be better than nothing and may actually be a stepping stone toward an administrative or quasiadministrative system. Judicial findings of liability could lead to the establishment of an administrative compensation scheme, either by creating pressure for legislative action or by leading a court to create some quasi-administrative mechanism with which to provide class relief in the remedy phase. 


\section{A. Administrative Compensation Schemes}

The desirability of compensation does not necessarily mean that a judicial forum is optimal. A legislatively established administrative system might offer several advantages over courts. ${ }^{175}$ It could operate under a more comprehensive set of rules. Transaction costs could be lower because agency expertise would produce more efficient decisions. It might also be easier for an agency to produce standardized protocols and payment schedules, which would also simplify the adjudicatory process. ${ }^{176}$

Although some features of the system were unique, the $9 / 11$ fund provides one model of an administrative compensation scheme.177 Such schemes provide a mechanism for social risk-spreading. Where the government is in part to blame for an event, such schemes may also

175 See Robert L. Rabin, Some Thoughts on the Efficacy of a Mass Toxics Administrative Compensation Scheme, 52 MD. L. REv. 951 (1993) for a discussion of the issues involved in designing such a system.

176 The ABA has recommended the use of administrative compensation, but largely as a back-up for judicial remedies rather than a substitute:

Government payment of compensation or additional assistance to persons affected by a major disaster should be considered when government is either implicated in the major disaster or public authorities determine that it is in the public interest to do so. Principles of equal treatment, due process and transparency should govern the distribution of compensation and disaster assistance.

American Bar Association, Rule of Law in Times of Major Disaster, Principle 7 (2007), available at http://www.abanet.org/litigation/ruleoflaw/rol_disaster.pdf. The commentary explains:

In cases where neither insurance coverage nor judicial action is likely to provide reimbursement for losses to persons affected by a major disaster, public authorities should consider providing reasonable compensation or additional disaster assistance to individual persons affected by a major disaster for losses when public authorities determine that it is in the public interest to do so, for example, where public authorities are responsible, through their action or inaction, for the disaster event or where public authorities determine that a remedy traditionally available either through the operation of the judicial system or otherwise should not be made available or should be severely curtailed. In such cases public authorities may provide for alternatives to judicial action to determine eligibility and fix awards. Public authorities should also be free to offer to persons affected by a major disaster, on a voluntary basis, a fair alternative to judicial action for the resolution of claims or the award of assistance.

Id.

17 For a recent appraisal of the fund, see Robert L. Rabin \& Stephen Sugarman, The Case for Specially Compensating the Victims of Terrorist Acts: An Assessment, available at ssm.com/abstract $=1097674$. 
provide a form of corrective justice, at least if we believe that the citizenry should take responsibility for the actions of their agents. On the other hand, an administrative compensation system would not penalize negligence by private parties who failed to take precautions against terrorism or other catastrophic events. Thus, an administrative system is best at risk-spreading, but not so good at deterrence or corrective justice unless the cost is shifted to the culpable parties.

Climate change might provide one setting for an administrative solution. In a previous article, I suggested the following possible scheme. ${ }^{178}$ A commission would receive claims from countries that have incurred adaptation expenses, such as strengthening sea walls or providing alternative sources of ecosystem services to replace lost wetlands. The commission would determine which adaptation expenses were reasonable, and would schedule them for compensation. Compensation might come directly from an international fund, but an alternative payment system might be more appealing if an international trading system for greenhouse gases was in place. In this alternative way of financing compensation, a set number of greenhouse gas allowances could be set aside for the commission's use. The commission would use these allowances to pay claims; in turn, the claimants could sell them to greenhouse gas emitters on the open market. The net effect would be that the sources doing the least to reduce their emission levels, which would have the greatest need to purchase additional emission permits, would indirectly provide compensation for the expenses of adaptation.

If an administrative compensation public risk is desired, should there be a permanent scheme for compensating public risks, or should ad hoc schemes be established after the fact? There are several arguments in favor of permanent compensation schemes providing umbrella coverage (or at least a default framework) for catastrophic risks. One argument for a permanent umbrella scheme is equity between victims. For example, the German government provided up to 8.1 billion euros in compensation for victims of a flood, but failed to provide similar compensation for victims of other disasters. ${ }^{179}$ Special funds were established in the Netherlands following a disease outbreak, a fire in a bar, and an explosion in a fireworks facility, with different procedures and levels of compensation for each of the three funds. ${ }^{180}$ Similarly, it seems unjust that the $9 / 11$ victims had the right to obtain government 
compensation, but not the victims of the Oklahoma City terrorist bombing.

Moreover, establishing a permanent scheme avoids the need for political wrangling about compensation after each event. Even if new legislation is required, having an established default scheme provides a framework for bargaining and should streamline consideration of legislative changes to deal with a particular catastrophic event.

On the other hand, the ex ante assurance of government compensation is clearly fatal to any possible private insurance marketas one scholar has said, "Solidarity kills market insurance." 181 Whether this is a serious problem depends on whether a viable insurance market is actually possible. But, as seen earlier, it is not clear whether private insurance markets for public risks are viable anyway. Advance assurance of compensation may also encourage forms of moral hazard, such as building in high-risk areas. Thus, a government compensation scheme may need to be coupled with some form of risk regulation or funded through risk-adjusted premiums.

As a practical matter, it may be difficult to establish a permanent compensation system for political reasons, and also because public risks vary so much in their characteristics. A compensation system for earthquakes would look very different from a compensation system for climate change. Ad hoc administrative systems remain a possibility. Their drawbacks are their unequal treatment of victims of different public risks and the potential for interest group influence on their formulation and implementation.

Litigation may have problems of its own, but does not suffer from these defects. Moreover, without the threat of litigation, the impetus for a legislative solution may not exist. Thus, initial resort to the courts may be a catalyst for a more satisfactory long-term solution, and may, in any event, be the only practical route for victims.

\section{B. The Feasibility of Judicial Remedies}

But can courts handle these cases? The manageability of claims depends in part on substantive law rather than procedure. Thus, we should consider how to shape liability rules for catastrophic risks that are both defensible on their own terms and conducive to effective procedural resolution. It is clear that much more work needs to be done in this realm, but a few preliminary thoughts are in order.

To begin, there should be a general presumption in favor of preventive relief, as exemplified by medical monitoring or removal of

Id. at 353 (quotation marks omitted) (citation omitted). 
hazardous substances. This form of relief has three key advantages. First, it obviates the need to engage in difficult individualized inquiries into whether individualized harms were caused by the defendant's conduct. Second, it does not raise the specter of unlimited, uninsurable liability for defendants, because preventive efforts are more easily forecast and generally lower than the ultimate damage to individuals that would result without precautions. Third, because preventive measures will be taken sooner, continuity of ownership is likely to be greater. At the time preventive measures are required, more of the stakeholders will have benefited from, or contributed to, the wrongful conduct, as opposed to the situation some years later, when catastrophic harm might typically eventuate.

Furthermore, when limiting the class of victims is necessary for manageability and fairness, the first priority should be the victims with the most catastrophic losses. This point is based on the significance of catastrophic risk liability as a form of risk-spreading, and it is those with the most severe harms who are most in need of insurance. Given equivalent losses, poorer individuals are more in need of insurance than richer ones. Thus, the families of the deceased, and individuals facing a risk of death, should recover before those with property losses or less drastic health effects. Similarly, those whose property is destroyed should get higher priority than those who suffer a lesser diminution in value. And losses that are otherwise covered by the insurance system should have lower priority than those that are not.

We should also favor claims where the causal connection applies generally to a class of victims, versus situations where the causal connection is highly individualized. The reason is obvious in terms of procedural manageability.

Turning from the plaintiffs to the defendants, courts should also be more inclined to impose liability for catastrophic risks where the defendants were negligent, or at least where the danger was known to them. This is important for deterrence purposes; it also bolsters whatever argument for corrective justice may apply. This should not be an absolute bar to stricter forms of liability, particularly when there are many individual defendants and it would be difficult or impossible to assess their individual culpability. It may also make sense to shift the burden of proof regarding culpability or liability shares to the defendants in order to expedite the litigation.

Under the best of circumstances, liability claims involving billions of dollars will pose challenges to judges and litigants. Procedural innovations can help, and so can sensitivity to manageability concerns in crafting liability rules. Manageability may sometimes require curtailing 
the class of victims or the form of relief, though courts should not jump to the conclusion without careful consideration of potential procedural solutions. In any event, manageability should rarely provide a justification for blanket immunity to entities that are responsible for causing catastrophic losses to others.

One of the positive lessons of the Strauss case is that we are not faced with an all-or-nothing choice. It may not be feasible to compensate all victims of catastrophic risks. Perhaps they are difficult to identify, or their damages are hard to assess, or their numbers would overwhelm the judicial system's procedural capacities, or the burden of liability would fall unfairly on innocent parties. Nevertheless, the unavailability of full compensation does not mean that all compensation should be denied. Strauss created a kind of triage rule, identifying a subclass of victims (those in privity of contract with the utility) whose claims seemed particularly deserving to the court. Although this truncation of the compensated group may not have been warranted, it does at least establish the possibility of cutting potentially unmanageable cases down to size. Providing partial relief to only some victims is not ideal, but it is better than providing zero relief to any victims.

\section{CONCLUSION}

In tort law, "big" is not necessarily "bad." The scale of litigation is not by itself a reason for courts to flinch. As the Restatement observes, "courts must be sensitive to the fact that some tortuous conduct may threaten, in a very clear way, massive harm and that merely the fact that the scope of liability is huge is not, of itself, a ground for imposing limits on it." 182 We have seen that there may be good reasons for imposing

182 Restatement (Third) of Torts, supra note 69 , at 599 ( $\$ 29$, comment $\mathrm{m})$. The Strauss case is ironic in this respect:

At base, the court feared that requiring compensation of all victims could bankrupt the company, disrupt its operations, and quite possibly result in the denial of the public of its basic need for electricity. This is an instance in which, had there merely been a single victim who was not a Con Edison customer (for example, a tenant whose electricity is paid for by the landlord), then (under the same facts) that victim clearly would have been able to recover compensation from the utility. Rather perversely, then, the fact that so many were harmed was what allowed the defendant to escape legal responsibility. (A different justification for this result might be that, when catastrophic results occur, if the defendant has to pay for all of the foreseeable consequences of its misconduct, this would be excessive "punishment." Yet, tort law normally does not require any relationship between the degree of fault and the amount of liability.) 
liability for catastrophic events on businesses or governments in terms of deterrence, risk-spreading, and perhaps to a lesser extent, corrective justice.

Too often, I believe, students leave their introductory tort courses with the sense that tort law is mostly a subject for personal injury lawyers and insurance companies, having little bearing on broader social problems. Providing compensation for victims of accidents, defective products, and malpractice is an important social goal, as is safeguarding valuable social activities against excessive liability. Thus, "everyday" tort law is important to society, not just to particular segments of the bar. In this sense, tort law is part of public law, not merely concerned with settling disputes between individuals fairly. ${ }^{183}$

But the significance of tort law is even broader. More importantly still, I believe, tort law can be relevant to some of the largest and most dramatic issues facing our society. Of course, tort law is not the only tool we have to use against threats such as terrorism, public health hazards, and climate change. It is not even the most important tool. Nevertheless, it can be a key part of our toolkit for responding to catastrophic risks.

Sugarman, supra note 165 , at 10-11. The courts' fear of bankrupting the company maybe excessive since Chapter 11 is designed to allow companies to continue operations and reorganize; in addition, bankruptcy risks are easily diversified through the securities markets. This is not to say bankruptcy poses no risks, and clearly innocent parties, such as workers or other creditors, may be harmed.

183 This public law perspective on torts, I believe, is the fundamental lesson of Guido Calabresi's classic Cost of Accidents, although it is probably remembered more often for introducing economic analysis into tort law. 
HeinOnline -- 43 Val. U. L. Rev. 1130 2008-2009 